\title{
Entradas missionárias e processos étnicos na Amazônia: o caso das missões jesuíticas de Maynas (c. 1638-1767)
}

Francismar Alex Lopes de Carvalho*

Resumo: $\mathrm{O}$ presente estudo analisa o papel que as entradas missionárias desempenharam na conformação territorial das missóes jesuíticas de Maynas e nas relações entre as diversas etnias envolvidas. As missóes de Maynas foram estabelecidas entre os índios que viviam nas franjas ocidentais da Amazônia, concretamente nos vales dos rios Marańón, Napo e Amazonas. A Companhia de Jesus, a serviço da monarquia espanhola, atuou na regiáo entre 1638 e 1767. As entradas missionárias eram expediçóes militares que tinham por objetivo atrair, por via da força ou da persuasão, os índios dos arredores para a vida em reduçóes. Prática corrente em outras missóes jesuíticas, as entradas eram realizadas, em Maynas, com uma frequência inaudita e foram comuns até às vésperas da expulsão da Companhia. É certo que essas expediçôes atendiam ao projeto missionário de expansão e consolidação territorial e às perspectivas de cada parcialidade ou etnia indígena de aumentar seus recursos humanos diante da rivalidade interétnica. Contudo, como procuro demonstrar para o caso amazônico, a perspectiva nativa, alterada pela situaçáo colonial, parece ter subsumido o programa missionário: as sucessivas entradas procuravam reduzir parcialidades que não aceitavam conviver em um mesmo pueblo; como resultado, o número de reduçóes tornou-se muito maior do que a capacidade dos jesuítas de atendê-las todas. Esse era um processo

\footnotetext{
* Pesquisador pós-doutoral da Fundação de Amparo à Pesquisa do Estado de Sáo Paulo (Fapesp) no Departamento de História da América da Universidade de Sevilha, Espanha, e no Departamento de História da Universidade de São Paulo. Doutor em História pela Universidade de São Paulo - USP. E-mail: francismardecarvalho@gmail.com.
} 
cíclico, pois a formação de novos pueblos com poucos moradores obrigava a novas entradas missionárias, para equilibrar e uniformizar a província.

Palavras-chave: Missôes jesuíticas. Amazônia. Expediçóes militares. Entradas missionárias.

No oye esta bárbara gente las voces del Evangelio si primero no suena el eco de la pólvora.

Padre Manuel de Uriarte, S.J. ${ }^{1}$

Si las necesidades son grandes, que confieso lo son; y tales, que me he visto a punto de perecer de hambre, ¿a quién no avergüenza ver que treinta soldados padecían la misma necesidad y plaga, por la vil codicia de unas pocas camisetas? Confieso de mí que me consume más esta consideración que la misma hambre.

Padres Gaspar Cujía, S.J., e Lucas de la Cueva, S.J. ${ }^{2}$

\section{Introduçáo}

A primeira epígrafe deste artigo provém de uma carta do padre Uriarte, que atuou nas missóes de Maynas nas duas décadas que precederam a expulsão dos jesuítas. O tema do uso da força militar como auxílio à expansão do Evangelho já fora tratado pelos melhores escritores da Companhia de Jesus. Significativamente, o padre José de Acosta (1984 [1588], liv. 2, cap. 12, v. 1, p. 339-341) era contrário à participação em entradas puramente militares, que se faziam com não pouco escândalo dos índios fronteiriços. "Sería mucho mejor dejar en silencio el nombre de Cristo que deshonorarlo", afirmava. Reconhecia, contudo, que era impossível aos missionários ir converter os "bárbaros" sem qualquer escolta defensiva, que dissuadisse os índios de atacá-los, "[...] siendo claro que no es posible acercarse a la mayor parte de los infieles a la antigua manera de los Apóstoles". ${ }^{3}$ 
Encontrava eco em alguns religiosos a ideia de que era legítimo o uso da força militar para defender os ministros da Palavra Divina; destarte, escreve o provincial padre Andrés Pérez de Ribas (1985 [1645], p. 123), em sua crônica da empresa jesuítica no norte da Nova Espanha para o período entre 1590 e 1645, que

[...] si los infieles impiden el predicarla [...]; y llega su rebeldía a tanto, que no contentos con no recibirla ellos, injustamente persiguen a los que movidos de Dios la reciben. En este caso ¿quien ha de amparar a estos afligidos y reprimir a los otros? Los Ministros Evangélicos no lo pueden hacer: no tienen fuerza, andan solos acompañados del auxilio divino.

Perguntava o mesmo religioso: quem duvidaria da necessidade de utilizar da força, ao menos nos estágios iniciais da missão, quando o demônio, como um leão bravo, vendo-se privado das almas que já possuía, valia-se dos feiticeiros para prejudicar, com toda a sorte de artifícios que estivessem ao seu alcance, o trabalho dos padres? (Ibidem, p. 124; cf. GREEN JR., 2011, p. 289 et seq.).

Nas fronteiras da Amazônia ocidental, como em outras partes, os jesuítas recorriam ao uso da violência (física e simbólica) em duas situaçóes bem concretas: em expediçóes militares dirigidas a atrair, pela força, índios “infiéis" às reduçôes ou destinadas a reprimir grupos recalcitrantes; e como recurso adiáforo no cotidiano da administração dos pueblos, por meio de castigos físicos, prisão, deportação etc. ${ }^{4}$ Missão religiosa e presídio militar, como lembra Hausberger (1993, p. 34, p. 40), mantiveram em toda a época colonial uma relação antes de tudo simbiótica: nas áreas fronteiriças do império, era raro ver um desprovido da companhia do outro..$^{5}$ Assim mesmo, os castigos físicos eram amplamente aceitos como indispensável recurso pedagógico, com o qual os próprios jesuítas foram educados (era típico, aliás, que os mestres não aplicassem diretamente o castigo em seus alunos, mas que os delegassem a fiscais) (HAUSBERGER, 1993, p. 34, p. 40).

Os padres jesuítas Lucas de la Cueva e Gaspar Cujía chegaram a Borja - uma pequena cidade de colonos espanhóis fundada em 1619, no vale do rio Marañón - a seis de fevereiro de 1638. Acudiam ao socorro espiritual dos moradores, desamparados pelos clérigos e outros 
religiosos mercedários e agostinhos, que se retiraram após uma revolta dos Maynas contra seus encomenderos. ${ }^{6} \mathrm{O}$ cenário, àquela época, náo era animador: sem encontrar o ouro esperado, não poucos espanhóis abandonaram a região, ao passo que os mais persistentes seguiam com entradas militares às terras baixas da Amazônia, com o objetivo de capturar indígenas para o serviço pessoal. "Hallamos levantada la tierra [...]”, informavam os dois citados jesuítas em 1640, “[...] porq' los Maynas, irritados con el trabajo y acosados con el servicio personal, tributos y extorciones con que les afligían, se levantaron, matando a treinta y tantas personas". ' Seja como for, de 1638 a 1660, os jesuítas realizaram intensas exploraçôes no vale do rio Marañón e reduziram os grupos Maynas, Jeberos e Cocamas. Entre 1660 e 1700, a missão expandiu-se às margens dos rios Guraray, Tigre e afluentes meridionais do Marañón. Finalmente, entre 1720 e 1767, fundaram a chamada "missão baixa", entre as sociedades Tupi dos rios Napo e médio Amazonas (GROHS, 1974, p. 124; TAYLOR, 1999, p. 223).

Dificuldades específicas experimentaram os padres da Companhia, entre as quais a impressionante diversidade linguística e cultural; o aguerrido faccionalismo, que obrigava à fundação de numerosas reduçóes; a falta de missionários; e a influência de escravistas portugueses. ${ }^{8}$ Os missionários reconheciam que a falta de produtos de alto valor comercial, de cuja exportação pudessem sacar recursos para manter mais religiosos e ofertar ferramentas, roupas e avelórios a contento dos índios, foi um fator decisivo que impediu que as missóes avançassem como esperado. ' Não é certo, entretanto, que as missóes de Maynas resultaram em um completo fracasso: o número de índios reduzidos passou de 7.966 almas, em 28 pueblos, em 1719, às 11.281 almas, em 21 pueblos, em $1768 .^{10}$

O presente estudo analisa o papel que as entradas missionárias desempenharam na conformação territorial das missóes jesuíticas de Maynas e nas relaçóes entre as diversas etnias envolvidas. As entradas missionárias eram expediçóes militares que tinham por objetivo atrair, por via da força ou da persuasão, os índios dos arredores para a vida em reduçóes. A primeira seção do texto apresenta as características principais dessas entradas, sua composição social, organização e direção, e as estratégias de que se valiam para lograr a transferência dos nativos do lado de fora para o lado de dentro das missóes. Após 
um breve exame das diferenças entre as entradas missionárias e as expediçóes punitivas, o texto passa ao problema central: por que, em âmbito amazônico, essas expediçóes eram realizadas com tanta frequência? Eram atividades que respondiam ao projeto missionário de expansão e consolidação territorial ou às perspectivas de cada parcialidade ou etnia indígena de aumentar seus recursos humanos diante da rivalidade que seguiu existindo entre os diversos grupos reduzidos? Os dados de que disponho até o presente momento permitem responder a essas questóes apenas com aproximaçóes.

Certamente, não parece de surpreender que os interesses do programa missionário e da guerra indígena confluíssem, pois ao fim e ao cabo o objetivo era aumentar o controle sobre recursos humanos. $\mathrm{O}$ núcleo da "ideologia da captura" entre os índios da América tropical residia, como argumenta Santos-Granero (2009, p. 175, et passim), numa busca por "civilizar" o Outro inimigo: "Slavery, therefore, is but a temporary status in a process through which enemy Others are civilized and transformed into intimate consanguines". Sob esse aspecto, os anseios dos missionários não eram de todo incongruentes com os dos caciques. Entretanto, nas sociedades das terras baixas, os cativos eram efetivamente "caçados" e incorporados, ao menos no início, como "mascotes". Com o tempo, podiam ser integrados, por meio do parentesco, como aliados e afins, vale dizer, "humanizados", processo que nem sempre dissolvia o status marginal decorrente da nódoa do passado cativo.

Contudo, como procuro demonstrar, a perspectiva nativa, alterada pela situação colonial, parece ter subsumido o programa missionário: as sucessivas entradas buscavam reduzir parcialidades que não aceitavam conviver em um mesmo pueblo; como resultado, o número de reduçóes tornou-se muito maior do que a capacidade dos jesuítas de atendê-las todas. Esse era um processo cíclico, pois a formação de novos pueblos com poucos moradores obrigava a novas entradas missionárias para equilibrar e uniformizar a província. As hostilidades entre as etnias e parcialidades, assim renovadas, reforçavam a atualidade da guerra indígena, que seguiu sendo influente, ainda que hibridizada com itens adventícios e metamorfoseada sob a forma de entradas missionárias. 
Em relação aos estudos anteriores, procura o presente trabalho avançar em um aspecto que não recebeu ainda a devida atençáo: a relaçáo entre a diversidade étnica e a estrutura administrativa das missóes. Para saber em que medida as entradas missionárias atendiam ao projeto jesuítico de expansão ou respondiam à rivalidade entre parcialidades e etnias pelo controle de recursos humanos, é preciso levar em conta o que os contemporâneos entendiam por parcialidades e naciones. $\mathrm{O}$ primeiro desses termos era empregado pelos funcionários coloniais para se referir a subunidades indígenas com distintas identidades residenciais e étnicas que formavam comunidades maiores ou haviam sido reunidas pela política colonial em reduçóes consolidadas; também podiam ser grupos que emergiram precisamente do contato colonial. Era reservado o termo nación para um conjunto de parcialidades que, segundo supunham os funcionários coloniais, falavam uma mesma língua e haviam-se originado de um mesmo local (RADDING, 2002, p. 63-64; 2005, p. 86-87; SAITO, 2014a; 2014b).

As missóes eram administradas por meio da delegação de tarefas de comando a índios destacados, inicialmente caciques, mas, com o tempo, também índios comuns treinados pelos missionários. ${ }^{11} \mathrm{O}$ essencial a notar aqui é que os jesuítas, ao integrar os nativos nas instituições municipais ibéricas, procuravam reforçar as divisóes entre as parcialidades e etnias. O cabildo exercia o governo municipal do pueblo, composto por um cacique governador, dois alcaldes, dois regidores $\mathrm{e}$ alguns alguaciles e capitanes, todos índios, eleitos no primeiro dia do ano por "los mayores del pueblo", ou seja, pelos caciques, oficiais militares e membros do cabildo anterior. ${ }^{12}$ Parece desnecessário recordar que os varayos, como eram chamados, tinham jurisdiçâo para prender e punir índios desviantes e cuidar da regularidade urbana da comunidade. ${ }^{13}$

A rigor, a eleição de cabildantes e capitanes de milicias não rompia com os antigos vínculos pessoais, antes se aproveitava deles em um novo patamar. Os postos do cabildo podiam ser preenchidos de forma rotativa entre as diversas parcialidades ou ocupados pela parcialidade mais importante da comunidade. Já os capitães de milícias eram eleitos segundo a quantidade de parcialidades existente, e sua jurisdição abarcava apenas os índios da sua respectiva parcialidade, sem que incidisse autoridade alguma sobre as demais. ${ }^{14}$ 
É nesse quadro que devem ser repensadas as funçóes das entradas missionárias. Como o cabildo, as milícias eram espaços para a reafirmaçáo das identidades das diversas parcialidades e etnias, visto que, embora não organizadas em hierarquias consistentes, a maior ou menor presença de uma delas na mesma comunidade proporcionava condiçôes para sua consolidação no poder.

\section{Modus operandi}

O componente básico de quaisquer entradas missionárias eram as milícias nativas. ${ }^{15}$ Em Maynas, deveu-se à iniciativa do governador Jerónimo Vaca de Vega, no início dos anos 1640, a formação de milícias em todos os pueblos de Maynas, e para tanto começou por nomear capitães, alferes, sargentos e cabos, dando-lhes seus títulos correspondentes: "declaró a todos los indios capaces de tomar las armas [...]", escreve um cronista, "[...] concediéndoles las exenciones, honores y gracias que lleva consigo el cargo y el oficio" (CHANTRE; HERRERA, 1901 [ant. a 1801], p. 605). Em pueblos compostos por naçóes distintas, foram formadas companhias correspondentes a cada nação, governada no militar, assim como já o eram no civil, por seus próprios oficiais. O serviço era obrigatório aos varóes em idade de dezoito a cinquenta anos. Os oficiais militares dispunham de insígnias de "[...] espontones y alabardas, las cuales usaban en sus marchas". Os alferes estavam munidos de bandeiras de tafetá, que exibiam uma cruz colorida em campo branco. Todos os capitáes levavam um bastáo com punho de prata, os alferes, uma lança curta com faca do mesmo metal e os sargentos e cabos de esquadra seus bastôes regulares. Era privilégio dos oficiais ter assento nos bancos de justiça (Ibidem, p. 606-607). ${ }^{16}$

A composição multiétnica dos pueblos de Maynas refletia-se no arranjo das entradas missionárias. Para ter-se uma ideia de quantos grupos podiam estar presentes em uma expedição, note-se a enviada em 1754 pelo missionário dos Andoas. Havendo fracassado, seis anos antes, a tentativa desses índios de atrair seus parentes que viviam espalhados pelos sertóes, em decorrência de terem sido atacados por certos índios independentes que viviam nas margens do rio Guasaga, o padre Camacho decidiu comandar uma nova entrada. Reuniu, então, 
uma poderosa armadilha composta por 250 índios de várias naçóes, Andoas, Simigaes, Pinches, Cahuapanas, Chayabitas, Paranapuras, Maynas, dois Jívaros, como intérpretes, e onze espanhóis. ${ }^{17}$ Outra expedição que contou com integrantes de várias etnias foi a enviada contra os Maynas "bárbaros”, em 1757. Foram nessa expedição 130 índios, entre Chayabitas, Paranapuras, Cahuapares, Jeberos e Lagunos, além de quatro colonos de Borja. ${ }^{18} \mathrm{Na}$ falta de suficientes milicianos, podia-se pedir ajuda aos índios ainda não reduzidos, como sucedeu com uma expedição contra os Jívaros, encarregada ao padre Viva, que contou com "[...] un tercio de Cunivos y otro de Semigayes, que aunque gentiles, eran tenidos por fieles y por valientes" (CHANTRE; HERRERA, 1901 [ant. a 1801], p. 304).

Dentre os milicianos dos vários pueblos, os que mais se destacavam nas entradas às terras de "infiéis", descobrimentos e pacificação de gentes novas eram os Jeberos de Concepción, por sua regularidade e obediência aos governadores e superiores das missóes. "Para recoger los fugitivos y castigar a los alzados, siempre se contaba con los Xeveros”, diz Chantre y Herrrera (Ibidem, p. 143), “[...] porque son indios de constancia en los trabajos, fieles, valerosos, muy prevenidos en los lances y avisados en los peligros [...]. Su rendimiento y subordinación a los que mandan es ejemplar, y en los mayores riesgos y peligros de la vida no saben jamás dejar su puesto”. Já pela década de 1650, os Jeberos eram descritos como cristãos antigos e exímios soldados, como assinalava uma carta ânua:

Ayudan a los padres en las entradas que hacen para conquistar más almas y fuera de que entre año viven como antiguos cristianos, en las cuaresmas es mayor el esmero de su piedad en oír gustosamente la palabra de Dios, en hacer sus procesiones y asistir con muestras de muy antigua religión a los oficios de Semana Santa. ${ }^{19}$

Não parece improvável que os jesuítas preferissem participar das entradas, em vez de delegá-las aos próprios índios, mas o dilema entre o imperativo de enviar expediçóes para atrair mais neófitos e o risco de pôr em estado de abandono os já reduzidos era amplamente reconhecido. Se as entradas podiam obter melhores resultados com 
a participação do missionário, conjeturava o padre Julián, coordená-las pessoalmente "[...] significaría tener que descuidar a los indios ya bautizados y dejarlos sin ayuda espiritual, incluso en peligro de muerte. El daño entre los fieles sería mayor que el fruto que cabría esperar entre los infieles". ${ }^{20}$

Era comum, em todo o caso, que o missionário não acompanhasse pessoalmente a entrada e delegasse sua coordenação a um cacique que, munido de presentes e instruído sobre o modo como devia tratar os "bárbaros", procurasse atrair alguns índios a que viessem ver como era a vida nas reduçôes (VELASCO, 1941 [1788], p. 266). É assim que, em 1654, o padre Raimundo de Santa Cruz, que atuava em Santa María de Guallaga, decidiu enviar uma entrada missionária aos Barbudos ou Mayorunas, conhecidos por serem "capitales enemigos entre si" e por comerem seus defuntos. Ofereceu-se o cacique Aconoma para essa empresa, e depois de recorrer as selvas por vários dias, deu finalmente com o acampamento dos Barbudos, que receberam a expedição com tambores e outros sinais infalíveis de guerra. Aconoma procurou mostrar aos Barbudos as ferramentas que havia trazido e mandou aos intérpretes que falassem na sua língua e lhes dissessem que vinha de paz e para estabelecer relaçóes e comércio com eles. Aderiram os Barbudos, enfim, à proposta de reduzirem-se em um pueblo na margem esquerda do rio Guallaga, em frente a Santa María. ${ }^{21}$ Seja como for, quando os índios independentes aceitavam reduzir-se, apareciam novos problemas e desafios, dentre os quais a delegação a alguns caciques da missão mais próxima da tarefa de conduzir os inícios na construção do novo pueblo, se o missionário já tinha demasiado trabalho com os pueblos dos quais cuidava. ${ }^{22}$

As entradas mais bem aparelhadas contavam com a presença do missionário, com cabos e soldados "espanhóis", em realidade, mestiços, chamados viracochas, armados de arcabuzes e fuzis, e uma boa tropa de indígenas, cem, duzentos, até quatrocentos, dirigida por oficiais nativos, munidos de lanças, escudos, arcos e flechas. A armadilha podia contar com dez, vinte e até cinquenta canoas. Para todos os casos, se o missionário estava presente, era tomado em qualidade de capitão (MAGNIN, 1998 [1740], p. 186-187; cf. TORRES-LONDOÑO, 2011, p. 355). Era comum, contudo, que espanhóis não tomassem parte, e mais de uma testemunha referiu que 
as entradas tinham maiores chances de serem bem-sucedidas sem a sua presença, o que esvanecia os receios dos índios de serem capturados para o serviço pessoal. ${ }^{23}$ Assim, por exemplo, os Jeberos impuseram aos padres Cujía e de la Cueva, em 1640, que somente aceitariam sua visita se não entrasse em suas terras o "Papené”: "[...] así llaman al diablo [...]", esclarecem os padres, "[...] y con este nombre apellidan al español". ${ }^{24} \mathrm{O}$ tema reaparece em 1684, quando o padre Tomás Santos, missionário entre os Gayes e Roamainas, tendo considerado conveniente transferir suas missóes para o rio Tigre, por considerar enfermiço o Pastaza, principiou por realizar uma entrada aos Pinches: "[...] lo primero que me preguntaron fue si venía español conmigo; y respondiéndoles yo que venía solo, se alegraron". ${ }^{25}$ Não era excepcional, ademais, que uma entrada malograsse devido aos desentendimentos entre os oficiais espanhóis e os caciques que serviam nas milícias. ${ }^{26}$

Reiteradas regulaçóes evidenciavam continuados abusos por parte dos espanhóis que acompanhavam as entradas missionárias e expediçôes punitivas. ${ }^{27}$ Uma Real Cédula emitida em julho de 1683 ao presidente de Quito ordenava que nenhum missionário intentasse entrar em terras de infiéis sem estar acompanhado de um cabo e alguma gente de guerra para a sua defesa. O cabo deveria estar às ordens do Superior das missóes e os soldados não podiam, por motivo algum, fazer repartimentos de índios, nem despojar a estes dos bens que lhes pertencessem. ${ }^{28}$ Contudo, os jesuítas registravam que abusos continuavam a ocorrer. Chega a referir o padre Widman as violências com que um "mulato" (assim diz o texto) e um português atuaram como cabos de entradas missionárias. Concretamente, em 1758, o irmão Gutiérrez Donado enviara o "mulato” Nicolás Perez e o português Francisco Gonzalez aos Alabonos e Iquitos, pelos rios Tigre e Eneracamu. Reuniram 110 almas, fora muitos que se perderam no caminho, uns fugidos, "otros muertos de necesidad y miseria". Amarraram-nos e trouxeram-nos por força a Alabonos, ação que teve más consequências, pois com tais excessos quedaram-se escandalizados os Iquitos das imediaçóes. Em pouco tempo, ademais, os Iquitos capturados começaram a desertar. ${ }^{29}$ Seja como for, não pretendiam os jesuítas dispensar esse auxílio, sendo recorrentes os pedidos que fizeram por mais soldados espanhóis nas missóes, assim para as entradas aos "infiéis" como para a defesa contra os portugueses. ${ }^{30}$ 
O primeiro objetivo dos jesuítas em suas entradas, e o mais imediato, consistia em atrair alguns "índios pagáos" a que visitassem as missóes. ${ }^{31}$ Como sucedia que o grupo considerado falasse uma língua estranha à dos já reduzidos, era preciso atrair ou capturar por via da força alguns índios e treiná-los como intérpretes. "Los tratamos regiamente", diz o padre Richter, "[...] los adoctrinamos y les enseñamos algo de la lengua inca. Cuando han aprendido lo suficiente como para servir de intérpretes, el misionero vuelve con ellos a las montańas y los indios les hablan a sus compatriotas de las bondades de la vida con los Padres". ${ }^{32}$ Embora pudessem ser trazidos violentamente ao pueblo, os lenguas deveriam ser bem tratados, sem serem obrigados a trabalho algum, como assinalavam as ordenaçôes do padre Gaspar Vivas. ${ }^{33}$

Mesmo munidos de intérpretes, era preciso dissuadir o receio dos "bárbaros" de serem feitos escravos dos espanhóis ou de seus inimigos indígenas, que amiúde participavam da expedição, a exemplo de certa etnia que confessou o temor de que "[...] aviamos de cautivar y llevar presos al Marañón o para esclavos de los Omaguas y Cocamas". Por esse motivo, o padre Maroni, no princípio da década de 1740, enfrentou a rivalidade entre os Auaricus “infiéis" e os Omaguas reduzidos insistindo para que os primeiros fossem visitar os pueblos dos segundos, para que "[...] viesen con sus propios ojos, quan falso era lo que les decían los ancianos, y formasen juntamente alguna idea del entable y gobierno de pueblos cristianos". ${ }^{34}$

Uma vez admitida a conversação entre o padre e as chefias nativas, a oferta de presentes caucionava as boas intençóes do convite para que visitassem a missão, o que ocorria alguns dias depois, sem esquecerem os índios de trazer ao padre alguns regalos. Este retribuía-lhes e lhes dava a entender que gostaria que formassem um pueblo cristão; que ninguém lhes faria mal algum, ou seja, que não serviriam em encomiendas aos espanhóis; e que haveria alguma tolerância com seus costumes: "[...] les asevera que podrían conservar sus cantos y bailes [...]", releva um jesuíta; “[...] y es de importancia, porque para ellos esto es decisivo". "Seriam providos de ferramentas e amparados contra as violências de seus inimigos, afiançavam os intérpretes. ${ }^{36} \mathrm{O}$ método geralmente resultava persuasivo, tanto mais porque dependia da oferta de ferramentas aos nativos. Em mais de uma oportunidade, ouviu o padre Richter dos índios o apreço que tinham pelos instrumentos de 
ferro, com que podiam talhar árvores, fazer sementeiras, construir casas, remover a terra, plantar banana, mandioca e outros itens. Lembrava ainda que ao padre Lucero, em certa oportunidade, um índio chegara a propor: "Toma, te regalo mi hijo y tú me das un hacha o una azada"; tendo ouvido a negativa do padre, o índio teria dito: "[...] hijos puedo engendrar todos los que quiero, pero jamás un hacha". ${ }^{37}$

Indispensáveis, portanto, às entradas missionárias eram a escolta armada e os presentes para ofertar aos índios, como resume o padre Magnin (1998 [1740], p. 184):

Hachas, cuchillos, agujas, utensilios de hierro, un misionero con la cruz en la mano, sandalias de cuero en sus pies, con una sotana remendada que no llega a media pierna para que no se enrede en las ramas y espinas, sin medias o calcetines, cubierto de viejo sombrero de paja, acompañado de un viracocha, fusil al hombro, estos son los preparativos necesarios.

Salienta um soldado espanhol a importância dos presentes ao referir que os padres "[...] no an hallado otro modo de atraer a esos barbaros a la amistad que dadibas, y regalos de herramientas, vestidos, y otros generos, que apetece su interesada codicia". ${ }^{38}$ Ferramentas eram o primeiro interesse dos índios, quando manifestavam querer reduzir-se, dado que percebiam a desvantagem dos seus antigos instrumentos em relação aos itens adventícios. Como assinala o padre Maroni (1988 [1738], p. 203): "[...] hachas, machetes, cuchillos y otros semejantes con que puedan hacer sus rocerías y buscar rocerías y buscar el sustento, pues con los instrumentos de piedra y hueso que usan cuando gentiles, les cuesta muchísimo trabajo el conseguirlo". ${ }^{39}$

A visita dos "infiéis" à redução, segundo a expectativa dos jesuítas, cumpriria a funçáo de ventilar, entre os índios independentes, a notícia de que um determinado grupo decidira reduzir-se, e que era provido pelo padre de ferramentas, vestido e outras coisas necessárias à vida humana. Assim, por exemplo, o padre Maroni esperava que os índios que viviam nos vales do Putumayo e do Aguaricu notassem o modo como viviam os já reduzidos nas missôes do rio Napo e chamassem, também, por missionários. ${ }^{40}$ 
De outro lado, os jesuítas aperfeiçoaram de tal modo a prática de realizar entradas missionárias que elas constituíam um aspecto importante do controle social interno das missóes. Os padres esperavam que o constante contato entre os índios reduzidos e os "selvagens" conscientizasse uns e outros das vantagens da vida urbana e política. É assim que o padre Fritz (1997 [1697], p. 119) considerava úteis as entradas bianuais "[...] a fin de tener sujetos a los indios recién convertidos [...]”, ou seja, como um método de controle interno. Esperava-se, portanto, que as entradas promovessem um duplo efeito disciplinar conducente a favorecer a evangelização dos índios: de um lado, a formação de milícias mais ou menos reguladas, segundo o modelo espanhol, podia promover a interiorização da obediência; de outro, a redução de uma nova parcialidade em um antigo pueblo ou em um pueblo anexo fomentava os sentimentos de distinção e de competição entre cristãos antigos e novos. ${ }^{41}$

Estratégias persuasivas e militares conformavam os procedimentos utilizados pelas entradas missionárias. Significativamente, eram chamadas de "cacerías" (MARONI, 1988 [1738], p. 203). A expedição não se aproximava de um assentamento indígena sem algumas medidas (dissimuladas) de assédio militar. ${ }^{42}$ Antes de mais, ocorriam durante a noite. Alguns índios adiantavam-se à comitiva, entravam furtivamente na comunidade, observavam a situação e, quando possível, subtraíam as armas dos moradores. ${ }^{43} \mathrm{~A}$ expedição apresentava-se de repente e com grande alvoroço, com o missionário a dizer "padre, padre", e os outros índios, "amico, amico", com o que se dissuadiam os receios e os hóspedes eram afavelmente recebidos. Se os nativos ofereciam resistência ou tentavam fugir, os milicianos que os esperavam armados diante das portas da aldeia forçavam à rendição. "Entonces se insinuaba el misionero con señales de paz [...]", escreve um cronista, "[...] y mostrándoles algunos regalos y donecillos, daba lugar a que se tratase de paces" (CHANTRE; HERRERA, 1901 [ant. a 1801], p. 613-614).

O escopo da expedição era, como já referido, retornar com meninos, especialmente filhos de caciques, que pudessem servir de intérpretes e que, uma vez observada a regularidade dos pueblos, dessem conta a seus parentes das vantagens da vida em redução. Se os 
índios não se dispusessem a entregar alguns jovens de bom grado, "[...] procuran los de la escolta coger al descuido alguno de los infieles y traérselo al padre, quien con muestras de cariño luego los sosiega [...]”, relata o padre Maroni (1988 [1738], p. 203); “[...] y una vez provechosamente engańado lo lleva consigo para su pueblo, donde con la crianza y comunicación, entrando en alguna policía y en la legua de los ya cristianos, sirva después de guía o intérprete para volver a sus tierras a amistar los demás". Reconheciam os jesuítas que, às vezes, era preciso recorrer à violência; uma entrada realizada em 1756 foi descrita da seguinte forma pelo padre Widman: "En una expedición que se hizo este año a distancia de 4 días del pueblo de Chamicuros se cogieron y trajeron por fuerza atados unos 17 barbudos" ${ }^{44}$ Excepcionalmente, uma entrada podia forçar o deslocamento de um contingente considerável, como sucedeu em 1692, quando o número de cativos ascendeu a 340 almas. $^{45}$

As entradas esbarravam em obstáculos de várias espécies e não raramente fracassaram. Não poucos grupos, apenas com intenção de receber as ferramentas ofertadas pelo padre, davam por vâs as promessas de que iriam reduzir-se e internavam-se novamente nos sertóes. ${ }^{46}$ Quando notavam, contudo, que a vontade sincera de aceitar o cristianismo era inseparável de uma inveterada resistência em abandonar sua pátria, alguns missionários não viam alternativa senão viver entre os "bárbaros" e tentar reduzi-los em sua própria terra. ${ }^{47}$ A hesitação dos curas em deixar os pueblos já fundados para acompanhar as entradas; o trabalho que custava lograr um grupo homogêneo e confiável de milicianos; a falta de pessoas práticas que pudessem servir de guias em regióes perigosas e desconhecidas; a carência dos regalos imprescindíveis para ganhar e manter a amizade dos índios selvagens - eram alguns dos entraves à realização das entradas, enumerados pelo padre Veigl (2006 [1785], p. 243). ${ }^{48}$

Náo era incomum que as expediçóes punitivas, uma vez ameaçadas, fossem obrigadas a retroceder. Em 1698, entrou a castigar o martírio do padre Enrique Richter, morto pelos Cunivos e Piros em 1695, uma armada de quarenta espanhóis oriundos de Lamas, Moyobamba e Borja, reforçados com quatrocentos guerreiros indígenas, sob o comando do capitão-mor Don Juan de la Rioja, e com 
a assistência dos padres Gaspar Vidal e Francisco Feijoo. Teve a expedição feliz sucesso ao princípio e recolheu muitos fugitivos, mas por um descuido (que não é informado) sofreu um severo revés, com morte de dezenove brancos e noventa neófitos. ${ }^{49}$

Em recente estudo sobre as missóes de Mojos, sugeriu A. Saito que a diferença entre entradas missionárias e expedições punitivas era de grau, não de espécie. ${ }^{50}$ Cenário semelhante náo parece de todo improvável, para o caso de Maynas, segundo pode-se haurir dos dados analisados no presente estudo. Em geral, as expediçóes punitivas eram uma resposta ao martírio de missionários e às hostilidades, reais ou supostas, cometidas contra espanhóis. Quando eventos assim sucediam, os presumidos autores fugiam da missáo, por certo, acompanhados de um bom número de moradores; se se tratavam de índios ainda não reduzidos, eles com frequência abandonavam seus assentamentos e internavam-se nos sertôes. As expediçóes punitivas, desse modo, perseguiam um objetivo análogo ao das entradas missionárias: conduzir quantos índios fosse possível dos sertóes para os pueblos, com o recurso à força, se necessário. Embora pudessem contar com a presença de um contingente mais numeroso de espanhóis, sempre acompanhados de centenas de soldados indígenas, as expediçóes punitivas também recebiam o aval dos missionários e, não incomumente, serviam-se deles como capelães. Os índios capturados, em todo o caso, eram divididos, os considerados culpados pela hostilidade que motivara a expedição podiam ser desterrados ou entregues como trabalhadores forçados para os espanhóis ${ }^{51}$ (chegou-se a aplicar a pena capital, como nota-se em mais de um exemplo); ${ }^{52}$ o restante era integrado às reduçóes existentes ou, se fosse o caso, podiam servir de intérpretes para atrair o restante do grupo a uma nova redução. Sucedia também que, a pretexto de capturar os autores das hostilidades e os neófitos fugitivos, as expediçóes punitivas capturavam e traziam às missóes quem quer que encontrassem pelo caminho. ${ }^{53}$

Como capelães das expediçóes punitivas, não deixavam os jesuítas de persuadir em favor de um tratamento moderado dos rebeldes e de zelar para que fosse conduzido às missóes o maior número possível de almas. ${ }^{54}$ Em não poucos casos, uma expedição punitiva poderia servir ao projeto missionário de instituir novos pueblos e aumentar os já fundados, tanto quanto as entradas enviadas pelos 
próprios padres. ${ }^{55}$ Apesar dos esforços de demarcar limites claros entre as expediçóes militares espanholas e as entradas missionárias, a finalidade última de capturar recursos humanos, ainda que para projetos distintos, tornavam-nos táo imprecisos quanto os marcos que separavam estas últimas da guerra propriamente indígena. ${ }^{56}$

Por mais que os jesuítas e os espanhóis que os auxiliavam tivessem aperfeiçoado o modus operandi das entradas missionárias, havia grupos que efetivamente impuseram uma audaz resistência à possibilidade de reduzirem-se. Tal era o caso dos Jívaros. ${ }^{57}$ Influíam sobre o ânimo dos jesuítas em empreender a conquista daquele gentio as presumidas vantagens da exploração de regiôes que, ao menos ao que se imaginava, abrigavam abundantes minas de metal precioso. Recorrentes e bem conhecidos, contudo, eram os insucessos e as desventuras daqueles que se lançaram à conquista dos Jívaros, sem que tais notícias advertissem o Superior de Maynas, padre Francisco Viva, sobre os riscos de semelhante empresa. ${ }^{58}$ Esse jesuíta dirigiu todas as suas atençóes ao tema e formulou uma estratégia alternativa para a realização de uma nova entrada aos Jívaros, que consistia no envio de uma expedição militarizada com o objetivo de capturar o maior número de índios possível, à maneira dos mamelucos portugueses. ${ }^{59}$

A estratégia do padre Viva foi levada adiante entre fins de 1691 e inícios de 1692, quando foi realizada uma nova entrada missionária aos Jívaros. Recursos para custeá-la foram acumulados quando o mesmo inaciano fora procurador das missóes, em tratos de cascarilla, cacau e vainilla sacados daqueles pueblos. Apresentado em Quito, recebeu o projeto o aval do presidente da Audiência e demais autoridades, pois não custaria nada à Real Hacienda. O fiscal, sem ser escutado, no entanto, lembrou que as cédulas reais mandavam que a conquista dos Jívaros fosse por meios suaves, e que os propostos pelo padre Viva não se lhe afiguravam assim. ${ }^{60} \mathrm{~A}$ Companhia cuidou de despachar aos comerciantes das cidades circunvizinhas uma poderosa quantidade de cascarilla e outros itens, que permitisse a aquisição de ferro para pagar as tropas e das provisôes necessárias. Teve início a expedição em outubro de 1691, sob o comando do governador de Maynas, Jerónimo Vaca de Vega, que dirigia uma tropa de sessenta soldados espanhóis e oitocentos índios em 130 canoas. Acompanhavam-na os padres Viva, Richter, Vidal e Narváez. Em poucas semanas, 
fora possível capturar uns 370 índios Jívaros, mas logo a expedição sucumbiu a duas adversidades: o estilo de guerra dos Jívaros, que evitavam a pugna aberta e arremetiam de surpresa, especialmente à noite; e a escassez de alimentos, que diminuíam à proporção do número de índios cativos que se incorporavam ao grupo. Pouco promissores, em todo o caso, mostraram-se os resultados dessa entrada: esfacelavam-se os vínculos de lealdade da milícia de Jeberos, com alguns caciques em atitude de aberta insubordinação; 260 Jívaros capturados eram repartidos, cem para as missóes e os demais entre os colonos espanhóis como encomiendas; e a efêmera povoação de Naranjos, fundada com alguns colonos pobres e índios capturados, assumia a forma de uma espécie de base militar para expediçóes de apresamento, com escândalo dos nativos que deveria atrair. ${ }^{61}$

A rigor, o método militarista do padre Viva fracassara. O padre Lucero, em carta de trinta de junho de 1697, dava conta do estado deplorável do pueblo de Naranjos:

El pueblo de los Naranjos [...] se halla casi destruido; apenas hay en él algunos indios. [...] Los Jíbaros se están en sus serranías, más difíciles de conquistar que nunca, por los agravios que han recibido con el pretexto de conquistarlos. Y aunque se han sacado a fuerza de armas más de 700 personas, han muerto los más de los cautivos en poder de los soldados que los recibieron como paga de sus trabajos. ${ }^{62}$

Era impossível fazer avançar a evangelização quando "estos soldados tratan y contratan con piezas de Jíbaros, como si fuesen piezas de ropa”. As expediçóes do padre Viva aos Jívaros e o pueblo de Naranjos, na opinião do padre Lucero, foram táo nocivos que os jesuítas estiveram a ponto de perder as missóes, dado o desprazimento geral, nas reduçóes antigas, com as ordens para que destacassem colonos para aquela fundação. ${ }^{63}$ Já em 1696 escrevia o padre Gaspar Vidal sobre a ruína daquele empreendimento: "muchos se ahorcan y desesperan; otros, desesperados, se echan a morir sin querer comer y beber; otros métense palos en la garganta y se ahogan". Como esse recurso à força deixara péssima impressão entre os índios, reconhecia o jesuíta que o projeto "ha sido un grave yerro". ${ }^{64}$ 
O primeiro apartado deste texto tratou de apresentar as características principais das entradas missionárias. Sua composiçáo social podia variar: havia entradas que contavam com a coordenaçáo de mestiços e a presença do missionário, mas não fortuitamente eram delegadas aos índios "cristãos", e compostas por pessoas de várias

etnias. Acercavam-se dos assentamentos dos chamados "índios bárbaros” sem serem sentidos e lançavam mão de estratégias persuasivas, sempre munidos de presentes, e de assédio militar, com o cerco da comunidade, para o caso de que intentassem resistir com mão armada ou fugir. Em termos militares, eram expediçóes híbridas: podiam contar com cabos espanhóis e presentes de itens adventícios, mas demandavam certas habilidades de mover-se, de encontrar rastros e pistas de comunidades dispersas no ecossistema amazônico, de aproximar-se sem se fazer notar e empreender um ataque repentino, que fazem pensar nas incursóes nativas e mesmo nas atividades de caça (SANTOS-GRANERO, 2009, p. 65, p. 73, p. 76). Provavelmente porque eram conduzidas pelos próprios índios, com frequência sem a companhia de espanhóis, e porque eram seguidas de métodos persuasivos, que consistiam em tratar bem os visitantes nos pueblos já fundadas, com a oferta de regalos e promessas de melhores condiçôes de vida, as entradas seguiam sendo uma forma imprescindível e efetiva de trazer gente para as missóes. Contudo, a escassez de recursos para fornecer regularmente ferramentas, roupas e avelórios aos índios, bem como a falta de missionários para dar conta dos numerosos pueblos que se formavam, levavam a que muitas reduçôes vissem sua existência encurtada, malgrado a promitente expectaçáo inicial.

\section{Parcialidades e etnias}

Em âmbito amazônico, reconheciam os jesuítas que, como não contassem com missionários suficientes, e dadas as circunstâncias da regiâo em que atuavam, não podiam ir além de fundar pueblos e de esperar que, quando o cenário se tornasse mais favorável e os recursos mais abundantes, fossem atendidos de modo satisfatório. $\mathrm{O}$ padre José Gumilla (1741, p. 239-242), por exemplo, utilizava a metáfora da horticultura para descrever a situação das missões amazônicas: 
em sua opinião, ainda que os pueblos do Orinoco padecessem da escassez de apóstolos, aqueles jardins haviam sido cultivados de tal forma que os nativos tinham lançado profundas raízes no terreno da fé. Mesmo que em períodos de seca essas plantaçóes espirituais parecessem lugares arrasados e mortos, reverdeciam e floresciam sempre que os jesuítas conseguiam regressar a elas. ${ }^{65}$ Mas como explicar que, nas terras baixas equatoriais, os jesuítas continuassem a constituir novos pueblos sem consolidar os já fundados?

Um primeiro aspecto a levar em consideração é o de que o limite da autoridade dos missionários, nessas regiōes, era ditado pela falta de recursos da Companhia para prover os neófitos dos itens adventícios mais desejados (SANTOS, 2009, p. 92). Como fossem diminutas as produçóes capazes de custear a aquisiçáo de itens europeus para os pueblos antigos, por essa mesma razáo, na expectativa de que algum novo descobrimento promovesse o fomento das missóes, os padres empreendiam novas entradas, despendiam os itens que possuíam, faziam novas promessas de presentes, que não podiam cumprir, e acabavam por deixar a todos insatisfeitos. Parece ilustrar essa assertiva o exemplo, mencionado anteriormente, da fracassada entrada aos Jívaros, organizada pelo padre Francisco Viva: esse Superior das missóes despendeu boa parte dos recursos que a província conseguira acumular na expectativa de que a reduçáo dos Jívaros permitisse a exploração de supostas terras auríferas. Nesse, como em outros casos, que as novas fundações fossem efêmeras e, nos pueblos antigos, fosse recorrente o problema da deserção, apenas sugere que esse método nem consolidava os pueblos já fundados, nem assegurava a adesáo das populaçóes novamente contatadas. Tinham os jesuítas, entretanto, outras opçóes?

Alvitram as evidências que as alternativas eram limitadas. Um problema incontornável seguia sendo a falta de missionários. Para todo o período em que os jesuítas administraram as missóes de Maynas, trabalharam ali, em média, uma dúzia de padres, que atendiam cerca de duas dúzias de pueblos, ao passo que, no Colégio de Quito, a média de residentes era de 65 religiosos. ${ }^{66}$ Nas missóes de Chiquitos, no oriente da atual Bolívia, entre 1724 e 1767, houve em média dezoito jesuítas para sete pueblos, ou seja, dois padres por pueblo, quase a proporção inversa de Maynas (TOMICHÁ CHARUPÁ, 2011, p. 347). Nessas condiçôes, compreende-se que, em uma 
carta de edificação a respeito de um missionário que recentemente falecera, conste que “[...] tanto más siente su desfallecimiento, quanto siempre va a más el numero de los pueblos, y a menos el de misioneros". A morte do padre Francisco Falcombeli sucedera em novembro de 1743, em San Ignacio de Pebas, em razão de uma enfermidade no estômago. ${ }^{67}$ Em Maynas, mesmo os irmãos estavam sobrecarregados com o trabalho missionário: ao irmão Francisco Herrera, por exemplo, "[...] entregole el superior tres reducciones, en que exercitase su fervoroso espíritu [...]", San Ignacio de Mayorunas, onde residia, San Joseph de Maparinas e Santa María de Guallaga. ${ }^{68}$

Consequência da proliferação de missóes e da falta de missionários, cada uma delas recebia insuficiente atenção. Cada religioso estava já abarbado com o cuidado simultâneo de vários pueblos. Escrevendo em 1728, o padre Zephyris dava conta de que estavam sob sua responsabilidade todos os grupos que viviam nas margens do rio Pastaza, que eram os "andoas, goes, semigoes, comacones, intermohones, machiones, macosihones, nevas, aracones, jarapas, pinches, roamaynas y pavas". "Una misión está tan lejos de la otra [...]”, lamentava o mesmo jesuíta, “[...] que no hay que extrañarse si por varios meses no podemos confesarnos sino a Dios" ${ }^{69}$ De não menos que uma dezena de pueblos deveria cuidar sozinho o padre Juan Lorenzo Lucero, segundo refere, em 1681, estando alguns táo distantes que era necessário viajar de mula, e outros que não via há quase seis meses, tempo hábil para que abandonassem a polícia e os rudimentos da doutrina cristã. ${ }^{70}$ Os jesuítas davam-se conta de como a situação era crítica ao terem de rechaçar os apelos de índios amigos por viverem em reduçóes, o que não podia suceder sem que os padres desamparassem as ovelhas já reunidas. Diante de tal dilema, escrevia o padre Julián que "[...] el daño para ellos es mucho más grande que el fruto que, tal vez, pudiéramos cosechar" ${ }^{71}$

Houve, é certo, tentativas de prevenir a proliferaçáo de missóes que náo podiam ser atendidas por missionário algum. Já em suas ordenaçôes de 1668, o padre Cavero havia acautelado aos padres a que não fizessem novas reduçóes sem consolidar as antigas: "Provéase de ministros de doctrina primeramente a los indios reducidos [...]", instruía no parágrafo sétimo de suas ordenaçôes, “[...] y no nos dilatemos a más naciones que las que pudiéramos beneficiar 
con los padres que hay, porque divirtiéndose a más se hará poco en todas partes, y porque no conviene prendarnos tanto hasta que haya sujetos para todo" ${ }^{72}$

Entretanto, essas ordens não foram obedecidas, e a dar crédito aos dados demográficos - evidentemente exagerados - aportados pelo padre Velasco, as entradas eram um recurso indispensável para repor as perdas decorrentes das epidemias. Assim, segundo informes do padre Lucero, compulsados pelo referido autor da Historia del reino de Quito, houve uma severa peste em 1660, mas nove anos depois a província recuperou-se devido às novas conquistas; a situação repetiu-se em 1669, com outra epidemia que ceifou um avultado contingente, mas as entradas missionárias puderam repor e superar, nos anos seguintes, o número anterior a $1660 .^{73}$

Não se deve sopesar, como um fator menor de alastramento das missóes, o carisma e a capacidade de sedução do padre Samuel Fritz. Nascido em Trutnov, Bohemia, em 1654, chegara às terras americanas pela década de 1680 e ao pueblo de Omaguas em 1686. ${ }^{74}$ $\mathrm{O}$ próprio missionário escreve que, mal havia iniciado os trabalhos entre os Omaguas, subiram de certa paragem do Amazonas 27 índios em canoas com desejo de conhecê-lo e escutar seus ensinamentos. Concluíram a visita com um convite para que o padre fosse aos seus assentamentos, o que não ele pôde recusar. Além disso, nos encontros iniciais, os jesuítas concentravam-se em oferecer aos índios promessas positivas de benesses materiais e espirituais, sem dar a entender que seus usos e costumes tradicionais seriam reprimidos. Assim, ao relatar uma de suas missóes volantes, reconhece o padre Fritz que permanecera treze dias entre os Guacaracasia "sin hacer nada”; exercitara sua paciência durante duas longas bebedeiras, "q.' hizieron p.a baylar las cabezas de los ticunas q.' avian muerto, aunque dezian q.' lo hacían por alegrarme"; "no se pudo impedir", justificava, "tenía q.' sufrir importunas visitas todo el día con los vayles y otros agasajos q.' entonces más me hazian". 75 Até 1692 , quando fora retido pelas autoridades portuguesas do Pará, fundara esse carismático apóstolo os alicerces de pelo menos trinta pueblos, que expandiram os limites da província a leste, embora fugazmente, até o sítio onde se encontra a atual cidade de Manaus. ${ }^{76}$ Responderam os portugueses com uma maior presença militar e missionária nos rios Negro e Solimóes, que 
pôs fim à maioria das missóes fundadas pelo padre Fritz. Sem haver convencido o vice-rei de Lima a enviar auxílio militar espanhol ao Marañón, e desprovido de meios para deter a expansáo portuguesa, expirou o referido padre na missão de Jeberos, em $1725 .{ }^{.7}$

Se a rivalidade com os portugueses era um obstáculo à expansão das missóes, a concorrência entre os jesuítas e as outras ordens religiosas parece ter impulsionado a criação de reduçóes que náo tiveram existência para além do papel. ${ }^{78}$ Essa era a opinião do capitão Guzmán y Salazar, que acompanhou a entrada dos franciscanos ao rio Ucayali, em 1691: verificou-se que os jesuítas já haviam estado naquele lugar, onde "[...] pusieron en ejecución en adelantarse a fabricar dicha iglesia y a introducirse con los naturales agasajándolos con solo llevarlos gallinas y gallos, y de camino entablar un torno de moler cańa dulce a mano de que hay mucha cantidad". Principiada a fundação, os jesuítas retiraram-se às missóes mais antigas, sendo digno de nota que "[...] no atendieron al pasto espiritual que pedía tanto gentío, asistiendo en él algún misionero, contentándose con dejar dichos dos indios lenguas en la fábrica y conseguida la primacía”. Ou seja, na opinião dos franciscanos, os jesuítas, naquela região, trabalhavam apenas para garantir sua jurisdição sobre um amplo território, sem efetivamente dar conta de evangelizar os nativos. ${ }^{79}$

$\mathrm{O}$ que diziam os franciscanos deve ser relativizado, porque a realização de sucessivas entradas missionárias não era exclusividade do método de evangelização dos jesuítas. Informes de freis que atuavam em outras partes da Amazônia assinalavam a falta de missionários e a sobrecarga de trabalho, com a obrigação de assistir a três ou mais pueblos distantes entre si, "[...] a cada uno de los quales asistían a costas de un sumo trabajo [...]", observava frei Pedro Magariños, a respeito das fundaçóes de Tarma, Cerro de la Sal, Río de las Amazonas, Jauja e outras,

[...] prq.' lo quebrado de los caminos, y la precisa e inevitable pensión de transitarlos a pié, y agua, por no ser posible otro tragín, por ser aquella tierra no solo desproveída 
de cabalgaduras, sino también por ser de suyo montuosas, y pantanosas, muy quebradas [...] por lo ardiente del temperamento. ${ }^{80}$

O certo é que as caixas reais não estavam dispostas a arcar com o financiamento de missóes que náo prometiam ingressos à Real Hacienda. Por essa razão, os missionários esperavam que, ao realizar continuamente novas entradas, lograriam descobrir algum gênero de alto valor comercial ou grupo indígena afeito ao trabalho constante, cujos frutos tirassem as missóes do atraso em que se encontravam.

A hipótese aqui defendida é a de que as sucessivas fundaçôes de novos pueblos, sem o cuidado de consolidar os já fundados, foram uma imposição do próprio mosaico de etnias que os jesuítas encontraram no Amazonas. A esse respeito, alude o padre Breyer que, como se não bastasse não existirem grandes "nações", uma tribo compondo-se de seis a doze linhagens ou casas, com cinquenta a cem famílias, o grande problema era que "entre las diferentes casas de tribus hay peleas y matanzas continuas". ${ }^{81}$ Receosas de eventuais hostilidades, "no sólo las parcialidades", escrevia o padre Zarate, "[...] sino también las familias mismas, viven apartadas las unas de las otras muchos días de camino”. As distâncias entre os assentamentos eram sumamente difíceis de percorrer, e era preciso que o missionário, a modo de caçador, andasse a peregrinar dias e ainda meses por bosques, rios e lodaçais, vivendo de frutas e caça existentes nas margens dos rios. ${ }^{82} \mathrm{O}$ faccionalismo era, portanto, um problema central, dado que as rivalidades tradicionais entre os grupos impedia sua reuniáo e conduzia à pulverização das reduçóes. ${ }^{83}$ Somente entre os Yameos estavam fundados, de 1723 a 1738, não menos de dezessseis pueblos, alguns compostos apenas pelos parentes e afins de um cacique, em razão das antigas inimizades que os impediam de residir juntamente com outros grupos nas reduçóes das margens do rio Marañón (JOUANEN, 1943, v. 2, p. 422).

A rigor, a escolha dos grupos a quem dirigir uma entrada missionária náo era aleatória. Ao labor do padre Widman, deve-se o registro de 39 expediçôes realizadas entre 1750 e 1761, as quais capturaram ou reduziram 2.713 índios. O jesuíta teve o cuidado de anotar os nomes das parcialidades e etnias que compunham cada entrada e os 
dos grupos a que pertenciam os cativos que trouxeram. O essencial a notar aqui é que a maioria dessas entradas - concretamente, 77\% não se dirigiram contra grupos independentes ou pouco conhecidos, mas contra desertores e parcialidades recalcitrantes de uma etnia já reduzida. ${ }^{84} \mathrm{~A}$ análise detalhada dessas entradas permite divisar que a reiteração de antigas inimizades, a dificuldade de convivência entre etnias e parcialidades, e as fugas constantes orientavam os objetivos perseguidos pelas expediçóes. Mais ainda: o esforço dos chefes por elevar o número de cativos sob seu poder, símbolos de prestígio que eram, seguia sendo o motor de uma guerra que podia beneficiar o projeto missionário, mas que este não poderia de todo controlar. ${ }^{85}$

Verifica-se aqui um determinante cultural indígena que terá influído poderosamente na formatação assumida pelas missóes de Maynas. Por trás das hostilidades entre etnias, parcialidades e outros grupos, vigorava a crença de que quaisquer males que pudessem recair sobre alguém, enfermidades, acidentes e mesmo a morte, eram causados por feitiços, vale dizer, resultavam de um ato deliberado de vingança. "Casi no ay quien muera [...]", escrevia o padre Magnin desde Borja, “q.' no se diga, q.' es por averle echo daño". ${ }^{86}$ Como fundar uma reduçáo se semelhante crença predominava entre os índios amazônicos? Nos inícios dos anos 1740, os padres Iriarte e Bastidas tiveram que condescender com os Encabellados e consentir que cada parcialidade formasse seu próprio pueblo, ainda que ao custo de multiplicar as fadigas do trabalho apostólico. Jouanen (1943, v. 2, p. 464), que documenta o episódio, sugere que continuava em vigor "[...] la repugnancia casi invencible que una parcialidad sentía para cohabitar con otra en un mismo pueblo, aun en el caso de que tuvieran entre si relaciones de amistad o parentesco". Dificuldade que nascia do temor que uns tinham de ser vítimas das "brujerías" dos outros. ${ }^{87}$

Náo parece excessivo supor que fatores ecológicos impedissem o agrupamento de índios em número que ultrapassasse o que fosse adequado às condiçốes amazônicas. Semelhante ponderação, contudo, não se afigurava óbvia para os missionários que, mesmo notando que os nativos viviam em agrupamentos de não mais de algumas poucas centenas de pessoas, intentavam reunir e formar grandes comunidades, à semelhança das reduçóes de milhares de índios que foram instaladas no Paraguai e que seguiam sendo um modelo para todas 
as outras. Como passava amiúde, após alguma empolgação inicial, motivada com a oferta de ferramentas, roupas, avelórios e outros itens, diversas parcialidades ensaiavam uma vida urbana conjunta, mas logo que escasseavam os produtos europeus, apareciam as epidemias e os antigos costumes eram proibidos, abandonava-se tudo, em sucessivas fugas ou em uma deserção generalizada. É assim, por exemplo, que, em 1742, julgou-se conveniente realizar uma entrada contra certa parcialidade dos índios Iquitos chamada Huasimoas. Os Iquitos viviam nas margens do rio Nanay e por aquela época eram reduzidos no pueblo de San Juan Nepomuceno pelo missionário José Bahamonde. $\mathrm{O}$ próprio governador de Maynas coordenou a expedição, acompanhado dos missionários Brentano e Bahamonde, oito soldados de Borja e um número competente de índios cristãos de várias reduçóes. Não foi necessário o uso da força, pois bastou a oferta de alguns dons para que os naturais aceitassem a vida em reduçôes. Três tribos prontamente juraram obediência ao governador e instalaram-se em dois pueblos, logo abandonados sem haver passado do estágio inicial e improvisado de formação (URIARTE, 1986 [1775], p. 448; JOUANEN, 1943, v. 2, p. 471).

Como explicar que os jesuítas continuassem promovendo sucessivas entradas missionárias quando o século XVIII já estava bem adiantado? Para esclarecer esse ponto, é preciso verificar qual a destinação dada aos índios capturados nas expediçôes. No livro de batismos do pueblo de La Laguna, que reunia Cocamas, Cocamillas, Panos e Chipeos, segundo verificou o padre Veigl, constavam alguns índios da nação Mananauva, trazidos das cabeceiras do rio Ucayale pela fracassada expedição punitiva de 1698. Esses índios haviam sido contatados pelo missionário martirizado padre Enrique Richter. Seu batismo em La Laguna ocorreu em 1704, e sua presença no livro de batismos até 1767 demonstra que não foram absorvidos pelas outras etnias. ${ }^{88}$ Seja como for, a permeabilidade e a diversidade étnica dos pueblos podem ter sido muito mais fluídas do que registraram os jesuítas. No pueblo de Loreto de Paranapuros, foram incorporados alguns Ticunas, trazidos do monte às vésperas da expulsão dos inacianos. Como "iban viniendo cada dia nuevos del monte a avecindarse", o livro de batismos somente registrava os Ticunas que fixavam chácaras próprias (URIARTE, 1986 [1775], p. 470). 
Para assegurar a reprodução de alguns pueblos, os jesuítas chegaram a promover as entradas missionárias a tal ponto que a etnia que dava nome à missão deixava de ser maioria. É o que sucedeu com o pueblo de Pebas, que em 1755 contava 630 almas, divididas entre as seguintes etnias: Cahuachis, 220; Ticunas, 138; Caumaris, 110; Yahuas, 88; e Pebas, $74 .{ }^{89}$ Dois anos depois, o número de Pebas era ainda menor no pueblo que levava seu nome, San Ignacio: Cahuachis, 217; Yahuas, 107; Caumaris, 88; Ticunas, 85; e Pebas, 53.90

Nada desautoriza a supor que houvesse uma tensão e um distanciamento entre os objetivos que os padres estabeleciam para as entradas missionárias e a atividade propriamente indígena de captura de cativos, em um contexto de rivalidade entre as parcialidades e etnias. As entradas missionárias às terras de "infiéis", muito provavelmente, davam continuidade, ainda que com novas e ambíguas justificativas, à guerra indígena. A situação de Maynas tenhá sido análoga à descrita por um estudioso para o caso das entradas que regularmente os neófitos das missóes de Mojos empreendiam contra as populaçôes circunvizinhas. Não poucas vezes sem a companhia do padre - e eventualmente sem a sua autorização -, os milicianos assaltavam de surpresa os naturais, cativavam quantos podiam e os conduziam à redução. Alojavam-nos em suas casas e submetiam-nos à sua "proteção". Aproveitavam-se os jesuítas desses descimentos porque realmente eram interessantes à propagação da fé cristá, embora a captura de recursos humanos elevasse o prestígio de certos chefes indígenas, em competição por influência política e distinção social (SAITO, 2014a; 2014b). ${ }^{91}$

Em Maynas, por sua vez, foram comuns as entradas movidas por iniciativa dos próprios índios. Os Omaguas, alegando que o sítio onde viviam era insalubre, manifestaram ao padre Bernardo Zurmillen, em 1723, que desejavam passar a montante do rio Marañón. Nos inícios da instalação do novo pueblo, capturaram alguns Yameos que viviam naquelas cercanias. Os cativos, entre eles um curaca, foram levados até o padre, que os regalou com ferramentas, avelórios, agulhas e outros itens, e depois foram devolvidos à sua aldeia. Apenas haviam passado alguns dias, quando começaram a vir Yameos de todas as partes em busca do padre, com esperanças de receber regalos. Com isso começou a amizade e comunicação entre os Yameos e os Omaguas, o 
que possibilitava sua redução em um mesmo pueblo. ${ }^{92}$ Alude o padre Widman que, em 1751, os Pinches, para obter mulheres com quem se casar, porque realmente contavam com poucas naquele momento, fizeram uma entrada (com a participação do próprio cura) para buscar cativas entre os Roamainas "cimarrones", que há onze anos haviam desertado para o mato. Lograram capturar 58 almas. Esse é um claro indício de que a guerra indígena, com suas motivaçóes relacionadas às relaçôes de parentesco, alteradas pela vida em reduçóes, seguia sendo um fator importante por trás das entradas missionárias realizadas em Maynas. ${ }^{93}$ Outra entrada que os neófitos fizeram por conta própria, para buscar seus parentes, ocorreu em 1748: os Andoas que se dirigiram ao rio Guasaga deram com alguns índios independentes, que os receberam com mostras de aberta hostilidade, mataram a dois expedicionários e feriram seis mortalmente. ${ }^{94}$ Nova entrada desse tipo sucedeu em 1759, quando os Ticunas do pueblo de Pebas foram em busca de seus parentes, e trouxeram a San Ignacio quarenta almas. É digno de nota que esse pueblo contasse com 650 habitantes, entre Caumares, Cahuachis, Yaguas, Pebas e Ticunas. Não parece de todo improvável, assim, pensar que os Ticunas preferiam ou tiveram que recorrer às entradas para buscar parentes e aumentar seu efetivo, em uma comunidade multiétnica onde, é de se presumir, tivessem talvez dificuldades de estabelecer casamentos. ${ }^{95}$

Para entender como a disputa de poder entre as parcialidades e etnias podia motivar entradas "missionárias" promovidas pelos próprios neófitos, convém retomar as distinçóes, feitas pelos jesuítas, entre o que viam como parcialidad ou nación. A parcialidade era um grupo de pessoas que acreditavam descender dos mesmos antepassados; rendiam culto a seu deus tutelar; e ocupavam um território que estava sob essa proteção divina. ${ }^{96}$ Já nação era um agregado de parcialidades que falavam uma mesma língua, e os seguidores de Inácio de Loyola não deixavam de notar certo sentimento de fraternidade existente entre alguns grupos, "o por la mucha cercanía, y vecindad", diz alguém, "[...] o por la semejanza en el modo de vivir, o por otras conveniencias, se han hecho amigos, y compañeros, y tienen entre sí grande hermandad". ${ }^{97}$

A rigor, a polícia dos jesuítas estava direcionada não à homogeneização, mas à criação de parcialidades e etnias uniformes, ou seja, não 
se tratava de dissolver as identificaçôes tradicionais, mas de moldá-las de modo a garantir uma governabilidade inspirada nas municipalidades ibéricas. Numerosos estudiosos já assinalaram a permanência das parcialidades nos cabildos, nas milícias e na divisão em bairros das missóes. ${ }^{98}$ Uma análise do papel das parcialidades e etnias nas entradas pode sugerir que a competição entre elas levava a que buscassem integrar "forasteiros", vale dizer, cativos capturados entre os "índios bárbaros" do entorno. Que algumas parcialidades ou etnias fossem muito mais numerosas que outras parece haver sido motivo de preocupação para as chefias nativas, que encontravam nas entradas missionárias uma oportunidade de afirmar sua participação no cabildo e influir sobre as decisóes do cura. Como a rivalidade entre os diversos agrupamentos era tal que o mais das vezes era impossível convencê-los a viverem juntos em um mesmo Pueblo. É de supor que estava em curso um processo de uniformização das parcialidades, mas não de homogeneização da província como um todo, dado que o resultado era uma pulverização de missóes que abrigavam, cada uma, um contingente reduzido de moradores. Parece ter sido esse o preço pago pelos jesuítas por consolidar as parcialidades para, por meio delas, garantir a governabilidade, pois eram seus chefes quem faziam as convocaçóes para as atividades coletivas ligadas à agricultura, às obras de construção, às cerimônias religiosas, às festas e às expediçóes militares.

\section{Consideraçóes finais}

As entradas missionárias continuaram a ser realizadas até a época da expulsão dos jesuítas, período que concerne a este artigo, não apenas porque os padres encontraram dificuldades específicas naquela região, que obrigaram à constante reposiçáo de neófitos nas missóes já fundadas e à construção de novos pueblos, não raro sem consolidar os já existentes. Continuaram a ser realizadas porque a economia da guerra propriamente indígena, ao condicionar as relaçóes entre etnias e parcialidades e, por conseguinte, a organizaçáo espacial do território das missóes, acabava por subsumir o projeto missionário. Como esperavam repor o contingente que morria em epidemias ou desertava das reduções, devido a rivalidades interétnicas, aversão à 
polícia cristã, descontentamento com a falta de ferramentas e outros itens europeus, os jesuítas não viam alternativa salvo dar continuidade ao envio de entradas missionárias. Ao fazer isso, submetiam o projeto missionário às antigas rivalidades entre etnias e parcialidades e aos anseios dos chefes indígenas por aumentar os recursos humanos sob seu controle. Uma vez capturada, boa parte das parcialidades e etnias não aceitava viver nas missóes já fundadas. $\mathrm{O}$ receio, que os missionários nunca conseguiram desterrar, de que as mortes e enfermidades eram resultado de feitiços de seus antigos rivais, levava à pulverização da província de Maynas em um número surpreendentemente elevado de pueblos, para a quantidade exígua de missionários disponíveis.

Ao contrário do discurso dos jesuítas em prol dos métodos persuasivos, as entradas missionárias - com o seu modus operandi militarizado - seguiram sendo enviadas até a época da expulsão da Companhia. A possibilidade de aplicar, com certa periodicidade, a força, a hostilidade e a agressão, moldou as relaçôes entre missionários, etnias e parcialidades. A pulverização das missóes terá sido uma consequência das disputas entre facçôes de índios apoiadores e opositores dos missionários. Mais uma vez, a negociação assimétrica, não a imposição, marcou a formatação das missões jesuíticas. Não se deve desprezar, portanto, os impactos da situaçáo colonial. De um modo ou de outro, a guerra colonial influiu poderosamente sobre a guerra indígena. Entradas missionárias e expediçóes punitivas não estavam desprovidas de traços característicos de expediçóes militares: ainda que nem sempre contassem com cabos espanhóis e armas de fogo, não dispensavam a hierarquia militar aos moldes ibéricos, as estratégias de assédio e os regalos adventícios. Não podiam retornar sem cativos, quer fossem obtidos pela persuasão ou pela força.

Em resumo, em um cenário em que o projeto missionário tivesse prevalecido, era de esperar-se que as entradas serviriam para elevar o número de moradores de um número limitado de povoaçóes mais ou menos uniformes. O que ocorreu, ao revés, foi que os índios parecem ter convencido os padres não apenas da necessidade da guerra, como também de que era infrutuoso obrigar grupos rivais a viver em um mesmo pueblo e que era preciso construir novas comunidades, até que se chegou ao ponto de que cada padre cuidava de três ou mais pueblos, que por isso mesmo podiam contar com certa margem de 
autonomia. Se a isso acresce-se que não poucas entradas missionárias eram enviadas sem missionário algum, e de própria iniciativa dos índios, nada desautoriza a supor que essa instituição foi em parte subsumida pela guerra indígena, o que representou um desvio significativo dos anseios do projeto missionário.

\section{Lista de abreviaturas e siglas dos arquivos consultados}

\begin{tabular}{|c|c|}
\hline AGI & Archivo General de Indias, Sevilla \\
\hline AGN & Archivo General de la Nación Argentina, Buenos Aires \\
\hline AHN & Archivo Histórico Nacional, Madrid \\
\hline AHPTCJ & $\begin{array}{r}\text { Archivo Histórico de la Provincia de Toledo de la Compañía } \\
\text { de Jesús, Alcalá de Henares }\end{array}$ \\
\hline ARSI & $\begin{array}{c}\text { Archivum Romanum Societatis Iesu, Roma } \\
\text { NR et Q: Fundo Nuevo Reino e Quito }\end{array}$ \\
\hline BNM & Biblioteca Nacional de España, Madrid \\
\hline BNVE & $\begin{array}{c}\text { Biblioteca Nazionale Centrale } \\
\text { Vittorio Emanuele II, Roma }\end{array}$ \\
\hline Comillas/ & $\begin{array}{r}\text { Universidad Pontificia Comillas, Biblioteca de la Sede Canto- } \\
\text { blanco, Colección Pastells, Serie Negra, Madrid }\end{array}$ \\
\hline RAH & Real Academia de la Historia, Madrid \\
\hline
\end{tabular}

\section{MISSIONARY ENTRADAS AND IDENTITY FORMATION IN AMAZONIA: THE JESUIT MISSIONS OF MAYNAS, C. $1638-1767$}

Abstract: This article examines the role of missionary entradas in the region of Maynas in relations between the diverse ethnic groups involved. The Maynas missions were established among the Indians who lived in the western fringes of Amazonia, specifically in the valleys of the Marañón, Napo, and Amazon rivers. The Company of Jesus was active in the region between 1638 and 1767. Missionary entradas were military expeditions that sought to attract Indians from the environs to live on reductions, either through force or persuasion. A common practice in other areas of Jesuit activity, in Maynas entradas occurred with an unprecedented frequency until the eve of Jesuit expulsion. These expeditions 
served both the missionaries' goals of expansion and territorial consolidation as well as those of indigenous contingencies of increasing their human resources in the wake of increased interethnic rivalry. Nevertheless, as I seek to demonstrate for the Amazonian case, indigenous realities subsumed missionaries' designs. Successive entradas attempted to place groups that did not accept living together in the same village; as a result, the number of reductions grew much larger than the capacity of the Jesuits to attend them. This was a cyclic process, as the formation of new villages with few residents impelled further missionary entradas to balance and make the province uniform.

Keywords: Jesuit missions. Amazonia. Military expeditions. Missionary entradas.

\section{Notas}

1 "Carta del Padre Manuel de Uriarte [...] a su hermano el señor Don Joseph Agustín de Uriarte, Inquisidor de Zaragoza”, Turiri, 6 nov. 1752 (In: Cartas edificantes [...], 1757, t. 16, p. 80).

${ }^{2}$ ARSI, NR et Q, 14, f. 151-152v, "Relación de la misión", Maynas, 25 out. 1640, f. $151 \mathrm{v}$.

${ }^{3}$ Três métodos de evangelização propunha o mesmo padre Acosta (1984 [1588], "Proemio", v. 1, p. 66-67) para o que distinguia entre três tipos de bárbaros. Povos "sin ley, sin rey, sin pactos, sin magistrados ni régimen de gobierno fijos, cambiando de domicilio de tiempo en tiempo", somente podiam ser convertidos pela força, vale dizer, por missionários que trabalhassem em companhia de soldados que protegiam as suas vidas. Era necessário forçá-los a juntar-se e a sair da selva, antes de compeli-los a entrar no reino dos céus com outros métodos. Naçôes como as dos Incas e Astecas, que possuíam cidades, formas de governo, magistrados e leis, podiam ser administradas por um governador cristáo que cuidaria de zelar pelo trabalho dos evangelizadores e reforçar continuamente sua adesão ao cristianismo. Por fim, somente entre as naçóes civilizadas da Ásia, como a China e o Japão, podiam os religiosos aplicar o mesmo método utilizado pelos apóstolos entre os gregos e os romanos, ou seja, o ensino pacífico e racional que não envolvia mudança de governo. Era considerado justo, portanto, obrigar os índios, pelas armas, a aceitar o cristianismo? Como releva Baciero (2006, p. 269, p. 271, p. 273), para o padre Acosta, não exatamente: a escolta militar que acompanhava os missionários servia para proteção, não para imposição. Por sua vez, no segundo volume de seu De Indiarum iure, publicado em 1639, Solórzano Pereira - distinto jurista espanhol, que conhecia de perto os problemas americanos -, retomava o padre Acosta e sua distinção de três classes de bárbaros, mas 
aceitava a coação indireta (por via da isenção de tributos e da oferta ou privação de privilégios), se o objetivo era unicamente fazer os índios aceitarem o batismo e a fé sem fingimento. Cf. Solórzano Pereira (1999, Lib. II, t. 1, cap. 9, n. 9-12, p. 321-323; 2000, Lib. II, t. 2, cap. 18, n. 22, p. 141 e n. 48, p. 151) e ver também: Maldavsky (2012, p. 87).

${ }^{4}$ Punições físicas foram recorrentes já nos esforços iniciais de conversão na Nova Espanha; ver: Clendinnen (1982, p. 33-36). Para as missóes de Maynas, ver as reflexões de Cipolletti (1999, p. 224).

${ }^{5}$ Nas missóes jesuíticas de Casanare, Meta e Orinoco, em vez de presídios, até 20 soldados fincavam residência em cada redução, de onde escoltavam os padres em suas jornadas (REY FAJARDO, 1995, p. 67-68).

${ }^{6}$ ARSI, NR et Q, 15, i, "Información jurídica a instancia del P. Lorenzo Lucero", 1684, f. 105. Cf. AGI, Quito, 11, r. 3, n. 37, "Relación de Pedro Vaca de la Cadena”, 1629; Jouanen (1941, v. 1, p. 328); Bayle (1949, p. 12-13); e Taylor (1994, p. 21-22).

${ }^{7}$ ARSI, NR et Q, 14, "Relación de la misión”, Maynas, 25 out. 1640, f. 151.

${ }^{8}$ As entradas missionárias e a diversidade étnica receberam a atenção de Bayle (1951, p. 46-47), Golob (1982, p. 151, 161-164), Stephan (2000, p. 91-94), Torres-Londońo (2011, p. 348, p. 350, p. 355) e Livi Bacci (2012, p. 155).

9 ARSI, NR et Q, 15, i, f. 114-114v, Enrique Richter a José Antonio de la Rentería, La Laguna, 19 set. 1686; AGI, Quito, 4, "Copia de carta del Padre Samuel Fritz", Pará, 1691, f. 328; "Wenceslao Breyer a su hermano", Santiago de la Laguna, 18 jun. 1699 (In: MATTHEI, 1969, v. 1, p. 254). Sobre a falta de recursos, ver também: Reeve (1993, p. 127-134).

${ }^{10}$ BNVE, Ms. Gesuitico 1249/1 (3378), all. I, "Catalogus Missionum Gentilium Societatis Jesu in Provincia Quitensi. Missiones Maynarum fluvii Marañon et Amazonas", 1719; BNM, Mss/17614, "Censo de las misiones de Maynas", Archidona, 15 fev. 1768, f. 35 [f. 75]-41 [81]; ver também: Golob (1982, p. 203). Essas cifras parecem razoáveis. Conforme apurou a visita de 1746, as 24 missōes contavam naquele ano com 7.780 almas (AGI, Quito, 191, "Informe del visitador Diego de Riofrío y Peralta", Madrid, 15 jun. 1746). Para efeitos de comparação, em 1746, as missóes de Chiquitos contavam com 14.701 moradores, segundo o censo de Francisco Xavier de Palacios; ver seu informe ao rei em: AGI, Charcas, 207, Plata, 22 ago. 1746.

${ }^{11}$ Numerosos autores destacaram as adaptaçôes que tornaram possível a aceitação do sistema municipal ibérico pelos índios (GIBSON, 1964, p. 182-191; LOCKHART, 1999, p. 53-67) e o papel de intermediários das chefias que participavam dos cabildos, interpeladas por demandas da colonização e dos índios comuns, às quais não podiam deixar de ter em consideração ( $v$.g: SPALDING, 1984, p. 227-229; RADDING, 1997, p. 170-175, 288-298; 2005, p. 168-192; WILDE, 2009, p. 212-223). 
${ }^{12}$ AGI, Quito, 242, n. 117b, "Copia del Ynforme hecho al Il.mo Señor Obispo de esta Diocesis por los Superiores que fueron de las Misiones", Manuel Mariano Echeverría y Francisco de Aguillar, Quito, 10 ago. 1784; o número de alcaldes e regidores é fornecido por: Chantre y Herrera (1901 [ant. a 1801], p. 594, 619); sobre a forma das eleiçôes: Comillas/CP, Serie Negra, Cuaderno n. 108, "Fórmula de entable", Provincial Baltasar Moncada [c. 1739-1743], f. 71.

${ }^{13}$ AGI, Lima, 1580, f. 3, "Consejo extraordinario", Fiscal, 23 mar. 1771; cf. Veigl (2006 [1785], p. 237).

${ }^{14}$ O que observava o padre Niclutsch (2012 [1781], p. 151-152) também passava em Chiquitos: AGI, Charcas, 293, "Testimonio de los autos originales de la visita y empadronamiento", Francisco Xavier de Palacios, 1746, f. 323 et passim. ${ }^{15}$ Sobre milícias missioneiras, ver, para o caso dos Guaranis: Kern (1982); Avellaneda (2005); Avellaneda e Quarleri (2007); e Takeda (2010a, 2010b, 2012); e para o caso de Mojos: Saito (2014a, 2014b).

${ }^{16}$ Ao que parece, devem ter sido raras as armas de fogo em mãos de indígenas, mas entre os Jeberos, Yameos, Masamaes, Payaguas, Pebas, Ticunas e Cavachis era comum o uso de setas envenenadas. Não foram adestrados nas evoluçóes de tropa regular, de resto inúteis no terreno amazônico. Mas acudiam aos alardos aos domingos e dias de festa, pela tarde, a fim de aperfeiçoar seu estilo próprio de guerra (AGI, Quito, 158, f. 246-257, "Relación de la misión apostólica”, Andres de Zarate, Quito, 30 out. 1735, f. 253v).

${ }^{17}$ Comillas/CP, Serie Negra, Cuaderno n. 108, f. 75-105, "Aditamento a los Apuntes", Adan Widman, c. 1762, f. 80-81.

${ }^{18}$ Ibidem, f. 96.

${ }^{19}$ ARSI, NR et Q, 12, i, "Carta Annua”, 1642-1652, Gabriel de Melgar, Quito, 1652, f. 43-43v.

20 "Juan Bautista Julián a un sacerdote", Jeberos [c. 1730] (In: MATTHEI, 1972 , v. 3, p. 260).

${ }^{21}$ Cf. Figueroa (1904 [1661], p. 114) e Jouanen (1941, v. 1, p. 391-392). A conquista espiritual dos Gayes seguiu o mesmo padrão: havidos por "índios bárbaros", formidáveis inimigos dos nativos do rio Pastaza, a quem derrotavam em guerras e comiam, tudo parecia indicar que os Gayes não receberiam o missionário de bom grado. Em 1668, encontrando-se no pueblo de Oas, delegara o padre Lucas de la Cueva ao índio intérprete Gaye chamado Pascual a missão de contatar seus parentes e atraí-los à amizade. Pascual fora municionado com anzóis, agulhas, telas para vestidos e seis machados. Os Gayes deram boa acolhida aos regalos e às intenções do missionário. Doze índios Gayes decidiram acompanhar Pascual até a missáo. Ali foram brindados com machados e outros itens. Três jovens permaneceram em Oas, a fim de serem treinados como intérpretes; o restante retornara à sua comunidade, a quem deviam comunicar os benefícios da vida em 
redução. Em 1668, foi enviado o padre Sebastián Cadeno, que servia de coadjutor em Archidona, como primeiro missionário dos Gayes, logo substituído pelo padre Agustín Hurtado, em 1672. O episódio vem narrado na carta do padre Lucas de la Cueva ao padre Hernando Cavero, datada de Oas, 24 fev. 1668 (In: MARONI, 1988 [1738], p. 254-255; cf. JOUANEN, 1941, v. 1, p. 462).

${ }^{22}$ Assim sucedeu com a construção do pueblo de Muratas: na ausência do padre, coube a alguns caciques principais do pueblo de Andoas a condução desse negócio. Esse tipo de delegação, como a experiência comprovava, não era imune a conflitos e desavenças: certo alferes Andoa, que permanecera entre os Muratas para industriá-los na formação do novo pueblo, enamorara-se de uma viúva Murata; o filho dela sentira-se ofendido e, auxiliado por comparsas, matara o referido alferes; os agressores, com suas mulheres e filhos e alguns parentes, em número de 54 almas, desertaram às terras dos Jívaros. De tudo tomaram satisfação os Muratas cristáos, que não faltaram em dar socorro à mulher e aos filhos do defunto Andoa, e solicitaram recursos ao padre para perseguir os culpados (Comillas/CP, Serie Negra, Cuaderno n. 108, "Aditamento a los Apuntes", Widman, c. 1762, f. 85, 91). ${ }^{23}$ AGI, Charcas, 382, "Memorial de don Juan Francisco de Castañeda, de la Compañía de Jesús”, 1720.

${ }^{24}$ ARSI, NR et Q, 14, "Relación de la misión", Maynas, 25 out. 1640, f. 152.

${ }^{25} \mathrm{RAH}$, Jesuitas, [s.n.], "Informe del P. Tomás Santos del viaje por el río Tigre", 1684 (In: Informes de jesuitas en el Amazonas, 1986, p. 345).

${ }^{26}$ AGI, Quito, 134, n. 10, Provincial de San Francisco, 18 jul. 1739, f. 2v.

${ }^{27}$ Madrid insistia "que estas escoltas se mantengan a la defensiva y no ataquen a los indios" (AGI, Quito, 210, Libro 5, f. 362v-364, "Real Cédula a la Audiencia de Quito", Madrid, 13 dez. 1694).

${ }^{28}$ AGI, Quito, 210, Libro 5, f. 79v-80, "Real Cédula al presidente de la Audiencia", Madrid, 15 jul. 1683.

${ }^{29}$ Comillas/CP, Serie Negra, Cuaderno n. 108, f. 49-67, "Apuntes de las cosas más memorables", Adan Widman, c. 1762, f. 58.

${ }^{30}$ AGI, Quito, 127, "Informe del P. Carlos Brentano", c. 1747, f. 7v. Esse ponto foi destacado por Bayle (1951, p. 46-47).

${ }^{31}$ Em vários informes, os missionários detalharam os procedimentos utilizados nas entradas. Ver, por exemplo: BNM, Mss/13530, f. 109v-121, Lucas de la Cueva a Francisco de Figueroa, San Miguel de los Avijiras, 22 mar. 1665, f. 114-117v; AGI, Charcas, 382, "Memorial de don Juan Francisco de Castañeda", 1720, 1-2v, 5; AGI, Quito, 158, "Relación”, Zarate, Quito, 30 out. 1735, f. 253v; AHN, Jesuitas, 251, n. 2, d. 8, "Origen, progreso y mutaciones de las XX reducciones del Napo", 1740, f. 227.

${ }^{32}$ Enrique Richter a Emmanuel Boye, Laguna, junto ao rio Huallaga, 1 jan. 1686 (In: MATTHEI, 1969, v. 1, p. 193). 
33 "De ninguna manera, con pretexto de que no estén ociosos, harán que los muchachos y muchachas que se sacan para lenguas hilen en torno" (Gaspar Vivas [c. 1680]. In: JOUANEN, 1941, v. 1, p. 625). Era amplamente reconhecido pelos missionários que, sem conseguir índios como intérpretes, a entrada devia ser considerada um fracasso: BNM, Mss/18577/21, "Cartas del P. Pedro Lozano [...], Córdoba de Tucumán, 21 de junio y 24 de agosto de 1732", f. 13v, 16, 17v; AGN, Sala 7, Biblioteca Nacional, 6235, "Anua", 1753, Miguel Streiger, f. 1, 3. ${ }^{34}$ AHN, Jesuitas, 251, n. 2, d. 8, "Relación de los Aumentos de la Misión de los Aguaricus este año de 1739”, Pablo Maroni [s.l.], f. 236v.

${ }^{35}$ Enrique Richter a Emmanuel Boye, Laguna, junto ao rio Huallaga, 1 jan. 1686 (In: MATTHEI, 1969, v. 1, p. 193).

${ }^{36}$ AGI, Quito, 158, "Relación”, Zarate, Quito, 30 out. 1735, f. 253v-254.

${ }^{37}$ Enrique Richter a Emmanuel Boye, Laguna, junto ao rio Huallaga, 1 jan. 1686 (In: MATTHEI, 1969, v. 1, p. 194).

${ }^{38}$ Esse depoimento consta no seguinte informe: AGI, Quito, 158, Nicholas Schindler ao tenente general da cidade de Borja, San Joaquín, 5 out. 1737, f. 259v. ${ }^{39}$ Numerosos testemunhos de outras regióes davam conta de que, sem presentes, não havia entradas. Ver, por exemplo: RAH, Numeración Nueva: 9-2274, f. 238v, Carta do missionário de Concepción de Manacicas [post. a 1708]. Os Guaranis, encorajados a atrair os Guenoas e outros grupos da Banda Oriental, deveriam ir bem providos de panos, tabaco, erva e outros resgates (AGN, Sala 7, Biblioteca Nacional, 140, "Preceptos de nuestros Padres Generales y Provinciales" [c. 1709], f. 8-8v).

${ }^{40}$ AHN, Jesuitas, 251, n. 2, d. 8, "Origen, progreso y mutaciones de las XX reducciones del Napo", 1740, f. 230. O missionário e procurador padre Manuel Rodríguez (1990 [1684], p. 407), de sua parte, escrevia: "Los bárbaros reconocían la decencia de los christianos, que ya se vestían, y aun les embidiaban los adornos y alajas con que los padres los enriquecían".

${ }^{41}$ Opiniáo semelhante à de Fritz emitiam missionários que atuavam em outras regiôes. Ver, por exemplo: AGI, Charcas, 384, Francisco Antonio de Argomosa Zevallos (informado pelos jesuítas), San Lorenzo, 6 fev. 1737, f. 4v; AGI, Charcas, 384, Bernardo Nusdorffer, Buenos Aires, 30 ago. 1745, f. 1v-3.

${ }^{42} \mathrm{O}$ estilo de aproximação e cerco não diferia essencialmente das incursões indígenas, como nota: BNM, Mss/18577/21, Pedro Lozano, "Córdoba de Tucumán, 21 de junio y 24 de agosto de 1732 ", f. 13v, 16, 17v.

${ }^{43}$ AGI, Quito, 158, "Relación”, Zarate, Quito, 30 out. 1735, f. 253v-254.

${ }^{44}$ Comillas/CP, Serie Negra, Cuaderno n. 108, “Apuntes”, Widman, c. 1762, f. 56. Em certos casos, era preciso afugentar um grupo inimigo para alcançar outro mais propício, como relevado em: RAH, Numeración Nueva: 9-2274, f. 227, Carta del P. Luis de la Roca [c. 1715]. 
${ }^{45}$ Tratava-se de uma expedição dirigida pelo padre Tomás Santos aos Andoas, reportada em: Enrique Richter a Francisco Viva, Santiago, 1 jan. 1692 (In: VARGAS UGARTE, 1945, p. 319).

${ }^{46}$ AGI, Quito, 328, Manuel Mariano de Echeverría, Quito, 10 fev. 1776, f. 830. ${ }^{47}$ AGI, Quito, 158, “Relación”, Zarate, Quito, 30 out. 1735, f. 254.

${ }^{48}$ As dificuldades eram tais que houve quem assinalasse que as entradas exigiam as mesmas habilidades da atividade da caça, ou seja, o domínio de certo sentido indiciário de conhecimento: "Es necesario fijarse hasta en los monos, si están asustados o parecen no tener miedo", alertava o padre Magnin (1998 [1740], p. 185), "porque si huyen es indicio de que hay gente cerca que los caza y al contrario, si no se asustan, están en el caso de los hombres que al no tener enemigos, viven tranquilos en sus reductos".

${ }^{49}$ Comillas/CP, Serie Negra, Cuaderno n. 108, f. 41-47, "Compendiosa noticia”, Veigl, c. 1767, f. 45.

${ }^{50}$ Ver os estudos de Saito (2014a; 2014b) e Avellaneda (2014). Golob (1982, p. 147 , p. 151 , p. 159 , p. $161-164$, p. 169) pontuou algumas características das expediçôes punitivas realizadas em Maynas.

${ }^{51}$ AGI, Patronato, 148, n. 1, r. 3, "Información de los méritos y servicios del capitán don Diego de Vaca de Vega", Borja, 4 jun. 1621, f. 2, e "Testimonio de Fray Lorenzo del Rincón”, f. 3v. Escreve o padre Figueroa (1904 [1661], p. 11) que, sob pretexto de capturar índios cimarrones, apóstatas e independentes, que atacavam os cristáos, "sacábase mucha gente de varias provincias, yendo en armada, cogiéndola y trayéndola en gruesas tropas que repartían entre los soldados y vecinos, que son las que llaman 'piezas"'.

52 Pelo menos dez caciques foram enforcados em uma expedição destinada a reprimir os Cocamas, Chipeos e Maparinas, que hostilizavam os missionários do rio Ucayali (AHPTCJ, M-179 (406) 2, Carta del P. Lucas de la Cueva al P. Provincial Gaspar Cujía, Quito, 5 out. 1665, f. 214-215). Outros exemplos em: ARSI, NR et Q, 15, i, "Información jurídica", Jerónimo Vaca de Vega, Borja, 23 set. 1683, f. 103-103v; e Magnin (1998 [1740], p. 188). O martírio do padre Figueroa, em 1666, levou a uma dura repressão contra os Cocamas, referida por Rodríguez (1990 [1684], p. 434-438), Velasco (1941 [1788], p. 339-341) e outros cronistas; dentre os historiadores modernos, ver: Jouanen (1941, v. 1, p. 451-455) e Golob (1982, p. 161-172).

${ }^{53}$ A captura, por expediçóes militares de espanhóis, de índios já contatados ou sob a influência dos missionários era tema de recorrente indisposição entre jesuítas e colonos. Ver, por exemplo: AGI, Charcas, 382, "Memorial de don Juan Francisco de Castañeda”, 1720, f. 1-2v, 5; AGI, Quito, 137, n. 32, Joseph Gonzalez, Macas, 17 mar. 1722, f. 291. 
${ }^{54}$ Em fins dos anos 1680, aproveitou-se o escarmento dos Cunibo do rio Ucayali, que deram morte ao irmão Francisco de Herrera, para reduzir a naçáo Tecuna, descida para o pueblo de Jeberos (ARSI, NR et Q, 15, i, "El P. Francisco Viva al P. Renteriale da quenta del estado de la misión del Marañón”, Jeberos, 15 set. 1687, f. 133v).

${ }^{55}$ Houve quem denunciasse os inacianos por vender as "peças" resultantes de suas entradas aos colonos espanhóis das cidades adjacentes (JOUANEN, 1943, v. 2, p. 432). Também no Orinoco, em fins do século XVII, tiveram os jesuítas que responder à denúncia de que promoviam descimentos forçados (RAUSCH, 1984, p. 71-72; REY FAJARDO, 1995, p. 43-46). Em seu célebre "Informe reservado", o marechal de campo Eugenio de Alvarado, escrevendo às vésperas da expulsão, e tendo em conta as missóes dos Llanos, diz que os padres procuravam conter o furor e o derramamento de sangue com "pláticas de paz", um grupo enviado com antecedência para convencer os nativos a receber afavelmente a expediçáo. $\mathrm{O}$ mais das vezes isso não sucedia, o que deflagrava desordens e violências que os padres não podiam evitar (Alvarado, Eugenio de. "Informe reservado", Madrid, 3 jan. 1767. In: REY FAJARDO, 1966, p. 260).

${ }^{56}$ Ao adiantar ferramentas, avelórios e roupas aos caciques, missionários e colonos esperavam que trouxessem certo número de cativos, mas como distinguia o procurador dos franciscanos que atuavam no rio Putumayo, a prática do "rescate" era particularmente perniciosa porque, para cumprir o compromisso ajustado com os espanhóis, os caciques podiam completar o número de cativos com índios da própria missão, vendidos por escravos (AGI, Quito, 200, Memorial de Frei Manuel de Cisneros al rey, Pasto, 14 fev. 1711, f. 846-846v).

${ }^{57}$ No início da década de 1680, empreendeu o governador Mauricio Vaca de Vega nova expedição contra os Jívaros, em atenção a uma das obrigaçôes do seu cargo, decorrentes das antigas capitulaçôes e notícias de que naquelas terras havia riquezas minerais. Foram reunidos cinquenta soldados espanhóis e mais de trezentos índios escolhidos de diversos pueblos de Maynas. O padre Lucero, que serviu de capelâo, aportou mais de 500 ferramentas de diversa espécie, com que comumente se pagava o soldo dos expedicionários. Ao tempo dessa expedição, os Jívaros habitavam as margens do rio Santiago, depois de sua confluência com os rios Paute e Zamora, onde antigamente existira a cidade de Logrońo, remansos que o sentir comum reputava auríferos. Apesar de terem recebido afavelmente os espanhóis, em pouco tempo mataram um sargento e quatro índios e fugiram, obrigando a expedição a retirar-se (Carta do padre Lucero ao vice-rei, datada de 23 ago. 1683 apud JOUANEN, 1941, v. 1, p. 482).

${ }^{58}$ Ver, por exemplo: AGI, Lima, 141, Alvaro Enriques de Castillo, Callao, 12 abr. 1613, f. 2; AGI, Quito, 14, r. 8, n. 34, Audiência de Quito, 20 mai. 1638; AGI, Quito, 210, Libro 5, f. 29-30v, "Real Cédula al Obispo de Quito", Madrid, 17 
set. 1680. Permanecia viva a tradição de que as cabeceiras dos rios da província de Jívaros sobejavam de ouro quando, na década de 1720, os descendentes do Marquês de Solanda pretenderam capitular aquela conquista com a Coroa, que denegou seu pedido. Ver memorial e parecer do Consejo de Indias em: AGI, Quito, 143, n. 20, "Memorial de Juan Bautista Sánchez de Orellana”, Quito, 29 fev. 1720, esp. f. 291v-292.

${ }^{59}$ Justificava o padre Viva a necessidade de uma entrada militar na crença de que, nos territórios dos Jívaros, havia um El Dorado, pois era certo, segundo a opinião geral, que "en cuios zerros está tanto oro, que no dudan afirmar acá y en España, que en todas las Indias no han descubierto tierra más riqua”. Assim atestavam certos papéis que estavam em Loja, provenientes dos ministros das Caixas Reais, em que constava que no território dos Jívaros existira uma cidade chamada Logroño, de cujas fábricas de minerar "en pocos años se dieron al rey unos millones de solo quinto" (ARSI, NR et Q, 15, i, "Propuesta del P. Fra.co Viva hecha en la ciudad de Pasto al P. Diego Fra.co Altamirano, visitador del Nuevo Reyno, en diciembre de 1689", f. 231v).

${ }^{60}$ AGI, Quito, 210, 1. 5, f. 362v-364, "Real Cédula a la Audiencia de Quito", Madrid, 13 dez. 1694.

${ }^{61}$ Cf. Jouanen (1941, v. 1, cap. 26, p. 512-516). Fundado em 1694, nas proximidades de onde se encontrara a antiga Logroño, destruída pelos mesmos Jívaros, o pueblo de Los Naranjos sucumbiu às entradas realizadas por colonos entre os índios daquelas cercanias, tendo capturado, em cinco anos, umas 670 almas. Não bastasse isso, constantes mortes por epidemias precipitaram o malogro do empreendimento (Ibidem).

${ }^{62}$ Carta do padre Juan Lorenzo Lucero, [s.l.] 30 jun. 1697 (apud JOUANEN, 1943 , v. 2, p. 390).

${ }^{63}$ Ibidem. Ver também: Maroni (1988 [1738], p. 279) e Chantre e Herrera (1901 [ant. a 1801], p. 304-305).

64 "Informe del P. Gaspar Vidal sobre Gívaros", 16 nov. 1696 (apud ASTRAIN, 1920, t. 6, p. 629).

${ }^{65}$ Sobre a metáfora da horticultura espiritual, ver: Cañizares-Esguerra (2008, p. 244).

${ }^{66}$ Estimativa obtida a partir dos catálogos disponíveis em: ARSI, NR et Q, leg.: 3, 5, 7 e 11; AHPTCJ, estante 2, caja 82 bis, leg. 1460, 45 (1 e 2); AHN, Jesuitas, 251, n. 2, d. 14; Idem, n. 21; e nas reproduçōes que facilita: Piñas Rubio (2011). ${ }^{67}$ ARSI, NR et Q, 15, ii, "Carta de edificación del difunto P.e Francisco Falcombeli, mis.o en Pebas, por P. Guil.o Grebmerser”, Laguna, 20 dez. 1743 [14 nov. 1745], f. 343.

${ }^{68}$ ARSI, NR et Q, 15, i, "Vida y muerte dichosa del Hermano Francisco Herrera Donado de la Compañía de Jesús”, por Pedro de Mercado, f. 115v. 
${ }^{69}$ Francisco Javier Zephyris a Hermenegildo Adam, Santo Tomás de Andoas, 3 jan. 1728 (In: MATTHEI, 1972, v. 3, p. 235).

${ }^{70}$ Carta do Superior Juan Lorenzo Lucero ao padre Vice-Provincial, Laguna, 3 jun. 1681 (In: RODRÍGUEZ, 1990 [1684], p. 514).

71 "Segunda carta del R.P. Juan Bautista Julián misionero en Quito y rector en Tacunga”, Jeberos [c. 1730] (In: GROSSER, 2007, p. 315).

72 "Órdenes del P. Hernando Cavero", 29 jun. 1668 (In: JOUANEN, 1941, v. 1, p. 621).

${ }^{73}$ Cf. Velasco (1981 [1789], p. 537). Os números com os quais trabalhava esse ilustre jesuíta orçavam em 100 mil os índios residentes em Maynas antes de 1660, 44 mil os que morreram na epidemia daquele ano e 20 mil os que padeceram na de 1669. Newson (1995, p. 313-314, 323) estima, a partir dos dados de Velasco, uma depopulaçáo de $63 \%$ nesse período, e sugere que as entradas podiam agravar as epidemias pois, ao trazer gente nova, eventualmente promoviam reinfecçóes. ${ }^{74}$ Cf. Gómez González (2011, p. 45). Ensaios de interesse para elucidar a biografia do padre Fritz podem ser lidos em: Pinto (2006).

${ }^{75}$ ARSI, NR et Q, 15-i, "El P. Samuel Fritz da noticia al P. R.or de Quito de las misiones de Omaguas", San Joaquín, 22 jun. 1686, f. 117v.

${ }^{76} \mathrm{Em}$ mais de uma oportunidade o jesuíta contestou a jurisdição portuguesa sobre áreas da Amazônia ocidental. Ver, por exemplo: AGI, Quito, 4, Fritz ao embaixador de Espanha em Portugal, Pará, 1691, f. 328.

${ }^{77}$ AGI, Lima, 89, Memorial do padre Samuel Fritz e parecer do vice-rei Conde de la Monclova, Lima, 14 set. 1692. Ver também o informe do padre Fritz sobre a atuação dos portugueses em: AGI, Quito, 158, "Ynforme del P.e Samuel Fritz", Jeberos, 23 mar. 1721, f. 174v-175v.

${ }^{78}$ Sobre a disputa de jurisdiçóes com os franciscanos, ver: AGI, Quito, 134, n. 10, Provincial de San Francisco Bartolomé de Alcano, [Quito] 18 jul. 1739, f. 2v; AGI, Quito, 158, Autos, 1755, f. 152.

${ }^{79}$ Guzmán y Salazar, Francisco de Rojas. "Declaración y diario que hizo”, Los Reyes, 12 nov. 1691 (In: BIEDMA, 1989, p. 194). Sobre a disputa entre franciscanos e jesuítas pelo rio Ucayali, em fins do século XVII, ver: Tibesar (1989, p. 40-43, 74-75) e Santos (2009, p. 87).

${ }^{80}$ AGI, Lima, 532, "Fr. Pedro Magariños, de la orden seráfica, provincial de la provincia de los doze apostoles de Jesus de Lima del Reyno del Perú”, Lima, 22 abr. 1750, f. 3v.

81 "Carta del P. Wenceslao Breyer a su hermano, sacerdote jesuita en Praga", Laguna, 18 jun. 1699 (In: MATTHEI, 1969, v .1, p. 252).

${ }^{82}$ AGI, Quito, 158, "Relación”, Zarate, Quito, 30 out. 1735, f. 253v. Cf. BNM, Mss/13530, Lucas de la Cueva a Francisco de Figueroa, San Miguel de los Avijiras, 22 mar. 1665, f. 113. 
83 "No estaban de mejor calidad los Aguanos por las guerras civiles, que havía entre sus parcialidades, porque [el cacique] Zaculuzepa llebaba muy mal el brío del Ebanicuro no olvidando los daños, que havía recivido de él" (AHPTCJ, M-179 (406) 2, Carta del P. Lucas de la Cueva al P. Provincial Gaspar Cujía, Quito, 5 out. 1665, f. 211-212).

${ }^{84}$ Comillas/CP, Serie Negra, Cuaderno n. 108, “Apuntes", Widman, c. 1762, f. 49-67, 75-105.

${ }^{85}$ Os jesuítas estavam informados de ocasióes em que os índios tentavam mover as entradas contra seus inimigos. Ver, por exemplo: RAH, Numeración Nueva: 9-2274, f. 229, Carta de Juan de Benavente, Concepción, 30 ago. 1717.

${ }^{86}$ AHN, Jesuitas, 251, n. 2, d. 3, "Relación de las cosas notables", Juan Magnin, Borja, 6 nov. 1743, f. 9. Ainda a esse respeito, ver: Niclutsch (2012 [1781], p. 124) e Veigl (2006 [1785], p. 230, 234).

${ }^{87}$ A repugnância das distintas parcialidades em se juntar num mesmo pueblo era motivo de lamentação também para os jesuítas que atuavam em Mojos: o padre Eder (1985 [c. 1772], p. 365), por exemplo, relata que diferentes grupos "se hostigaban con permanentes odios y guerras", e que "aunque éstas han cesado, hasta ahora sigue clavada en los espíritus su memoria y aun cierto resabio de odio". Certamente tem validade para todo o âmbito amazônico a observação de um autor anônimo de que, ainda que os membros de diferentes parcialidades frequentassem uma mesma lagoa ou rio, eles preferiam tomar diferentes caminhos e rodeios, de modo a que não se encontrassem: "assi los pueb.s están hechos un labirinto en contorno de camin.s" (AHPTCJ, estante 2, caja 84, 2-2, "Descripción de los mojos", 1754, f. 5).

${ }^{88}$ Comillas/CP, Serie Negra, Cuaderno n. 108, f. 41-47. "Compendiosa noticia", Veigl, c. 1767, f. 46.

${ }^{89}$ Comillas/CP, Serie Negra, Cuaderno n. 108, "Apuntes", Widman, c. 1762, f. 54. ${ }^{90}$ Comillas/CP, Serie Negra, Cuaderno n. 108, "Aditamento a los Apuntes", Widman, c. 1762, f. 97.

${ }^{91}$ Como assinala Santos-Granero (1992, p. 12 et seq.) para a Amazônia ocidental, na perspectiva da guerra indígena, os cativos que resultavam de sucessivos conflitos podiam ter três destinos: morte, venda e servidão. Aspecto duradouro das redes de intercâmbio entre as diversas etnias, a busca por cativos incrementou-se enormemente sob a influência dos adventícios. Segundo sabe-se sobre o caso de Mojos em particular, uma vez que as presas das entradas chegavam à redução, todas as crianças eram imediatamente batizadas e distribuídas entre as diversas parcialidades que participaram da expedição, de acordo com critérios próprios de honra e status. Alguns cativos, contudo, podiam ser entregues ao missionário como "domésticos", ou seja, servos perpétuos do padre (SAITO, 2014a; 2014b). 
${ }^{22}$ Pablo Maroni a Angel Maria Manca, La Laguna, 21 dez. 1731 (In: MARONI, 1988 [1738], p. 379).

${ }^{93}$ Comillas/CP, Serie Negra, Cuaderno n. 108, "Apuntes", Widman, c. 1762, f. 51.

${ }^{44}$ Comillas/CP, Serie Negra, Cuaderno n. 108, "Aditamento a los Apuntes", Widman, c. 1762, f. 80.

${ }^{95}$ Ibidem, f. 86.

${ }^{96}$ ARSI, Peru, v. 17, f. 102-109v, "Carta del P. Antonio de Orellana al P. Martín de Jáuregui”, Loreto, 18 out. 1687, f. 104. O estudo de Saito (2014a) chamou a minha atenção para essa passagem e para a referida na nota seguinte.

${ }^{97}$ ARSI, Peru, v. 20, f. 200-213, "Carta de los Padres", 20 abr. 1676, f. 202. Sigo aqui, além dos trabalhos de Saito já citados, Radding (2002, p. 63-64; 2005, p. 86-87).

${ }^{98}$ Ver especialmente os trabalhos de Takeda (2010a; 2010b; 2012) e Tomichá Charupá (2011), além dos de Saito.

\section{Referências}

ACOSTA, José de, S.J. De Procuranda Indorum Salute [1588]. Madrid: CSIC, 1984, v. 1, 1987, v. 2.

ASTRAIN, Antonio, S.J. Historia de la Compañia de Jesús en la asistencia de España. Madrid: Razón y Fe, 1920, t. 6.

AVELLANEDA, Mercedes. El ejército guaraní en las reducciones jesuitas del Paraguay. In: PAGE, Carlos A. (ed.) Educación y evangelización: la experiencia de un mundo mejor: X Jornadas Internacionales sobre Misiones Jesuíticas. Córdoba, Argentina: Universidade Católica, 2005, p. 117-128.

Las misiones jesuitas de Chiquitos y el proceso de esclavización en las tierras bajas del Oriente boliviano (1691-1764). Trabalho apresentado nas $X V$ Jornadas Internacionales Misiones Jesuiticas, Pontificia Universidade Católica de Chile, 2014, Santiago, Chile.

AVELLANEDA, Mercedes; QUARLERI, Lía. Las milicias guaraníes en el Paraguay y Río de la Plata: alcances y limitaciones (1649-1756). Estudos Ibero-Americanos, Porto Alegre, v. 33, n. 1, p. 109-132, 2007.

BACIERO, Carlos. Juan de Solórzano Pereira y la defensa del indio en América. Hispania Sacra, Madrid, v. 58, n. 117, p. 263-327, 2006.

BAYLE, Constantino, S.J. Notas sobre bibliografía jesuitica de Mainas. Madrid: Jura, 1949.

. Las misiones, defensa de las fronteras. Mainas. Madrid: Jura, 1951. 
Entradas missionárias e processos étnicos na Amazônia:...

BIEDMA, Manuel, O.F.M. La conquista franciscana del Alto Ucayali. Iquitos: IIAP: CETA, 1989.

CANIIZARES-ESGUERRA, Jorge. Católicos y puritanos en la colonización de América. Madrid: Marcial Pons, 2008.

CARTAS EDIFICANTES, y curiosas, escritas de las missiones estrangeras, y de levante por algunos missioneros de la Compañia de Jesus. Madrid: En la Imprenta de la Viuda de Manuel Fernandez, 1757, t. 16.

CHANTRE Y HERRERA, José, S.J. Historia de las misiones de la Compañia de Jesús en el Marañón español: 1637-1767 [ant. a 1801]. Madrid: Impr. de A. Avrial, 1901.

CIPOLLETTI, María Susana. Jesuitas y Tucanos en el noroeste Amazónico del siglo XVIII: una armonía imposible. In: NEGRO, Sandra; MARZAL, Manuel M., S.J. (Eds.). Un reino en la frontera: las misiones jesuitas en la América colonial. Lima: PUCP, 1999. p. 223-241.

CLENDINNEN, Inga. Disciplining the Indians: Franciscan Ideology and Missionary Violence in Sixteenth-Century Yucatán. Past \& Present, n. 94, p. 27-48, 1982.

EDER, Francisco Javier, S.J. Breve descripción de las reducciones de Mojos [c. 1772]. Cochabamba: Historia Boliviana, 1985.

FIGUEROA, Francisco de, S.J. Relación de las misiones de la Compañia de Jesús en el país de los Maynas [1661]. Madrid: Victoriano Suárez, 1904.

FRITZ, Samuel, S.J. Diario [1686-1723]. Quito: Academia Ecuatoriana de la Lengua, 1997.

GIBSON, Charles. The Aztecs under Spanish rule: a history of the Indians of the Valley of Mexico, 1519-1810. Stanford: Stanford University Press, 1964.

GOLOB, Ann. The Upper Amazon in historical perspective. 1982. Thesis (Ph.D.) - City University of New York, 1982.

GÓMEZ GONZÁLEZ, Juan Sebastián. La frontera selvática: historia de Maynas, siglo XVIII. 2011. Tesis (Doctorado) - Universidade Nacional Autónoma de México, 2011.

GREEN JR., Robert L. Masters of Idolatry: Catholic Colonialism, Jesuit Conversionary Thought, and Indigenous Religious Traditions in the Spanish Pacific World, 1568-1672. 2011. Dissertation (Ph.D.) - University of California, Santa Barbara, 2011.

Anos 90, Porto Alegre, v. 23, n. 43, p. 321-366, jul. 2016 
GROHS, Waltraud. Los indios del Alto Amazonas del siglo XVI al siglo XVIII: poblaciones y migraciones en la antigua provincia de Maynas. Bonn: Udo Oberem, 1974. GROSSER, José, S.J. (Ed.). Las misiones de Mainas de la Antigua provincia de Quito de la Compañía de Jesús. Quito: Biblioteca Ecuatoriana Aurelio Espinosa Pólit, 2007. GUMILLA, José, S.J. El Orinoco Ilustrado, historia natural, civil, y geographica de este Gran Rio, y de sus caudalosas vertientes. Madrid: Manuel Fernández, 1741. HAUSBERGER, Bernd. La violencia en la conquista espiritual: las misiones jesuitas de Sonora. Jahrbuch für Geschichte Lateinamerikas, n. 30, p. 27-54, 1993. INFORMES de jesuitas en el Amazonas, 1660-1684. Iquitos, Perú: IIAP-CETA, 1986. JOUANEN, José, S.J. Historia de la Compañía de Jesús en la antigua provincia de Quito: 1570-1773. Quito: Ecuatoriana, 1941, v. 1; 1943, v. 2.

KERN, Arno Alvarez. Missóes: uma utopia política. Porto Alegre: Mercado Aberto, 1982.

LIVI BACCI, Massimo. Amazzonia: L’impero dell'acqua, 1500-1800. Bologna: Il Mulino, 2012.

LOCKHART, James. Los Nahuas después de la conquista: historia social y cultural de los indios del México central, del siglo XVI al XVIII. México: Fondo de Cultura Económica, 1999.

MAGNIN, Juan, S.J. Descripción de la Provincia y misiones de Mainas en el Reino de Quito [1740]. Quito: Biblioteca Ecuatoriana Aurelio Espinosa Pólit, 1998.

MALDAVSKY, Aliocha. Vocaciones inciertas: misión y misioneros en la provincia jesuita del Perú en los siglos XVI y XVII. Sevilla: CSIC, 2012.

MARONI, Pablo, S.J. Noticias auténticas del famoso río Marañón y misión apostólica de la Compañia de Jesús [1738]. Iquitos, Perú: CETA, 1988.

MATTHEI, Mauro (Ed.). Cartas e informes de misioneros jesuitas extranjeros en Hispanoamérica. Santiago, Chile: Pontificia Universidad Católica, 1969, v. 1.

MATTHEI, Mauro (Ed.). Cartas e informes de misioneros jesuitas extranjeros en Hispanoamérica. Santiago, Chile: Pontificia Universidad Católica, 1970, v. 2.

MATTHEI, Mauro (Ed.). Cartas e informes de misioneros jesuitas extranjeros en Hispanoamérica. Santiago, Chile: Pontificia Universidad Católica, 1972, v. 3.

NEWSON, Linda A. Life and death in early colonial Ecuador. Norma: University of Oklahoma Press, 1995.

NICLUTSCH, Francisco, S.J. Noticias americanas de Quito y de los indios bravos del Marañón [1781]. Quito: Cicame: Fundación Alejandro Labaka, 2012. 
PÉREZ DE RIBAS, Andrés, S.J. Páginas para la historia de Sonora: Triunfos de nuestra santa fe [1645]. Hermosillo: Gobierno del Estado de Sonora, 1985. PIÑAS RUBIO, Francisco, S.J. Catálogo de la provincia de Quito de la Compañia de Jesús en la Colonia: 1586-1767. Alicante: Biblioteca Virtual Miguel de Cervantes, 2011. PINTO, Renan Freitas (Ed.). O Diário do Padre Samuel Fritz. Manaus: Editora da Universidade do Amazonas, 2006.

RADDING, Cynthia. Wandering peoples: colonialism, ethnic spaces, and ecological frontiers in Northwestern Mexico, 1700-1850. Durham: Duke Univ. Press, 1997.

Comunidades en conflicto: espacios políticos en las fronteras misionales del noroeste de México y el oriente de Bolivia. Desacatos, México, n. 10, p. 48-76, 2002.

Landscapes of Power and Identity: comparative histories in the Sonoran Desert and the Forests of Amazonia from Colony to Republic. Durham: Duke University Press, 2005.

RAUSCH, Jane M. A tropical plains frontier: the Llanos of Colombia, 1531-1831. Albuquerque: University of New Mexico Press, 1984.

REEVE, Mary-Elizabeth. Regional Interaction in the Western Amazon: The Early Colonial Encounter and the Jesuit Years: 1538-1767. Ethnohistory, v. 41, n. 1, p. 106-138, 1993.

REY FAJARDO, José del, S.J. (Ed.) Documentos jesuiticos relativos a la historia de la Compañia de Jesús en Venezuela. Caracas: Academia Nacional de la Historia, 1966.

. Las escoltas militares en las misiones jesuíticas de la Orinoquia, 16611767. Boletín de la Academia Nacional de la Historia (Venezuela), v. 78, n. 311, p. 35-69, 1995.

RODRÍGUEZ, Manuel, S.J. El descubrimiento del Marañón [1684]. Madrid: Alianza, 1990.

SAITO, Akira. Consolidación y reproducción de las parcialidades tras la implantación de las reducciones en el Moxos jesuítico. Trabalho apresentado nas $X V$ Jornadas Internacionales Misiones Jesuiticas, Pontificia Universidade Católica de Chile, 2014a, Santiago, Chile.

. La guerra indígena y la expansión misional: El caso de Moxos, siglos XVII-XVIII. Trabalho apresentado nas XV Jornadas Internacionales Misiones Jesuiticas, Pontificia Universidade Católica de Chile, 2014b, Santiago, Chile.

SANTOS-GRANERO, Fernando. Etnohistoria de la Alta Amazonia: siglos XVI-XVIII. Quito: Abya-Yala, 1992. 
Vital enemies: slavery, predation, and the Amerindian political economy of life. Austin: University of Texas Press, 2009.

SANTOS, Roberta Fernandes dos. A expressão da vontade: relaçóes interétnicas e rebelião indígena nas missões de Maynas (1685-1698). 2009. Dissertação (Mestrado em História) - Pontifícia Universidade Católica de São Paulo, 2009.

SOLÓRZANO PEREIRA, Juan de. De Indiarum iure: (Liber II, De acquisitione Indiarum). Madrid: CSIC, 1999, t. 1 (cap. 1-15), 2000, t. 2 (cap. 16-25).

SPALDING, Karen. Huarochiri: an Andean society under Inca and Spanish rule. Stanford: Stanford Univ. Press, 1984.

STEPHAN, Jörg. Spanische Herrschaft und Mission in der Grenzprovinz Maynas: 1619-1768. Stuttgart: Heinz, 2000.

TAKEDA, Kazuhisa. ¿Continuidad u ocaso? Transformación del poder de los jefes étnicos en las misiones jesuíticas del Río de la Plata. Trabalho apresentado em: Simposio 'Las reducciones indígenas: una visión comparativa'. Lima, Pontificia Universidad Católica del Perú, 2010a.

. Organización social de las misiones guaraníes: relación entre la parcialidad y la milicia. Trabalho apresentado em: XIII Jornadas Internacionais sobre as Missóes Jesuiticas: fronteiras e identidades: povos indígenas e missões religiosas. Dourados, Universidade Federal da Grande Dourados, 2010b.

. Cambio y continuidad del liderazgo indígena en el cacicazgo y en la milicia de las misiones jesuíticas: análisis cualitativo de las listas de indios guaraníes. Revista Tellus, Campo Grande, ano 12, n. 23, p. 59-79, 2012.

TAYLOR, Anne C. Estudio introductorio. In: TAYLOR, Anne C; LANDÁZURI N., C. (Eds.) Conquista de la región Jivaro, 1550-1650: relación documental. Quito: Marka: IFEA: Abya-Yala, 1994, p. 1-30.

. The western margins of Amazonia from the early sixteenth to the early nineteenth century. In: SALOMON, F.; SCHWARTZ, S. B. (Eds.) The Cambridge history of the native peoples of the Americas: South America, v. 3, part 2. Cambridge: Cambridge University Press, 1999, p. 188-256.

TIBESAR, Antonino, O.F.M. Introducción: la conquista del Perú y su frontera oriental. In: BIEDMA, Manuel, O.F.M. La conquista franciscana del Alto Ucayali. Iquitos: IIAP: CETA, 1989, p. 15-79.

TOMICHÁ CHARUPÁ, Roberto. Población indígena y diversidad cultural en Chiquitos (siglo XVIII). Algunas consideraciones. Trabalho apresentado na XXV Reunión Anual de Etnología, Museo Nacional de Etnología y Folklore, La Paz, 2011. 
TORRES-LONDOÑO, Fernando. A cristianização nos confins: missionários, soldados, índios amigos e índios a converter: atores e papéis nas crônicas de Maynas. In: AGNOLIN, Adone et al. (Org.) Contextos missionários: religião e poder no império português. Sáo Paulo: Hucitec: Fapesp, 2011, p. 341-360.

URIARTE, Manuel Joaquín, S.J. Diario de un misionero de Maynas [1775]. Iquitos: Monumenta Amazónica, 1986.

VARGAS UGARTE, Rubén, S.J. Manuscritos peruanos en las bibliotecas de América. Buenos Aires: [s.n.], 1945.

VEIGL, Francisco Xavier, S.J. Noticias detalladas sobre el estado de la provincia de Maynas en América meridional hasta el año 1768 [1785]. Iquitos: CETA, 2006.

VELASCO, Juan de, S.J. Historia moderna del Reyno de Quito y Crónica de la Provincia de la Compañia de Jesús del mismo Reyno [1788]. Quito: Impr. de la Caja del Seguro, 1941.

- Historia del reino de Quito en la América meridional [1789]. Caracas: Biblioteca Ayacucho, 1981.

WILDE, Guillermo. Religión y poder en las misiones de guaranies. Buenos Aires: SB, 2009.

Recebido em: 14/05/2015

Aprovado em: 20/09/2016 